\title{
Socioeconomic Determinants of Renewable Energy Production in Emerging and Developed Countries
}

Suzanna Elmassah ( $\nabla$ suzanna.elmassah@zu.ac.ae )

Cairo University Faculty of Economics and Political Science https://orcid.org/0000-0002-2254-5736

\section{Research Article}

Keywords: Renewable energy, autoregressive distributed lag model, panel cointegration; emerging countries, developed countries, sustainable development

Posted Date: June 3rd, 2021

DOl: https://doi.org/10.21203/rs.3.rs-554269/v1

License: (c) (i) This work is licensed under a Creative Commons Attribution 4.0 International License. Read Full License 


\title{
Socioeconomic Determinants of Renewable Energy Production in Emerging and Developed Countries
}

\author{
Author Name: Suzanna Elmassah \\ Institutions: Zayed University, College of Business, Abu Dhabi-UAE \\ Cairo University, Faculty of Economics and Political Science, Egypt \\ email addresses: Suzanna.elmassah@zu.ac.ae \\ suzanna.elmassah@feps.edu.eg \\ Postal Address: Zayed University-AUH campus14453-UAE
}

ORCID: 0000-0002-2254-5736

\section{Declarations}

Availability of data and materials

The datasets during and/or analyzed during the current study available from the corresponding author on reasonable request.

\section{Competing interests}

The author declares that they have no competing interests.

\section{Funding}

No funding received.

\section{Authors' contributions}

Single author.

\section{Acknowledgements}

Not applicable.

\begin{abstract}
Energy is essential for development and economic growth, but traditional non-renewable energy sources are finite and have significant adverse environmental impacts. Therefore, there is an increasing interest in energy generation from renewable sources. However, research to date in this field does not sufficiently identify the common factors determining the uptake of renewable energy in emerging and developed countries. This paper addresses that gap by identifying the complex interrelationships between factors that determine the extent to which countries convert to renewable energy. The article's primary focus is a detailed statistical analysis of 10 developed and 16 emerging countries using annual data from 1976-2018. The objective is to examine the interrelationships and elasticities between increased production of renewable energy and three key socioeconomic variables; GDP, $\mathrm{CO}_{2}$ emissions, and oil price. This research uses panel data and time-series analyses to identify panel and country-specific elasticity of renewable energy production and dynamic causal relationships between these variables. It also applies fully modified and dynamic ordinary least square approaches. The study details the different interactions between the variables in each country. It uses an autoregressive distributed lag model to determine the long and short-run dynamics between renewable energy production and the three variables in each country. The paper shows there was a long-run elasticity between renewable energy and GDP in
\end{abstract}


the developed countries and short-run dynamics between renewable energy and the other two variables. Whereas in the emerging countries category, there were long-run relationships between renewable energy and GDP, CO2 emissions, and oil price.

Keywords: Renewable energy; autoregressive distributed lag model; panel cointegration; emerging countries; developed countries; sustainable development.

JEL classifications: C22; C32; Q21, Q43 


\section{INTRODUCTION}

Energy is a strategic resource for global development and prosperity. It plays a significant role in enhancing the social and economic standards of living globally (Ali, Anwar, \& Samina, 2017). Traditional non-renewable energy sources include coal, nuclear, oil, and natural gas, whereas renewable energy resources include solar, wind, water (hydro), biomass, and geothermal. Renewable energy initially required significant subsidies to compete with traditional fossil fuels. But due to increasing research and development (R\&D) and more focus on sustainability, renewable energy costs have decreased significantly in the last few years (IRENA, 2019). The global demand for energy in 2017 was 13,972 million of tons of oil equivalent (Mtoe), consisting of $86.2 \%$ non-renewable energy and $13.8 \%$ renewable energy (IEA, 2019a). In 2018, renewable energy production contributed more than $26 \%$ of total global electricity generation (REN21, 2019).

The world is vulnerable to future challenges such as climate change, increasing greenhouse gas emissions, the depletion of non-renewable energy resources, and ever-increasing demand for energy due to population growth. The extensive use of fossil fuels as the primary source of energy (since the Industrial Revolution) threatens the sustainability of resources for future generations (Akar, 2016). The production of gas and oil reserves is expected to drop by $40-60 \%$ by 2030 (IEA, 2012). Furthermore, non-renewable energy is the primary source of carbon dioxide $\left(\mathrm{CO}_{2}\right)$ emissions and the major culprit for greenhouse gases and, subsequently, climate change ((Halder, Dirmeyer, \& Saha, 2015); (Akar, 2016)). There United Nations has promoted debate and efforts to reduce global emissions (such as the Kyoto Protocol of 1997, the Doha Amendment of 2012, and the Paris Agreement of 2016). The World Bank also emphasizes that improving clean energy access is one of the main drivers to alleviate poverty and promote sustainable economic growth (Akar, 2016).

Global prioritization of these issues has created some positive impacts. Around 95 countries showed improvement in their overall Energy Translation Index, an index that analyzes each country's readiness to adopt clean energy using the three criteria of energy access and security, environmental sustainability, and economic development and growth (World Economic Forum, 2020). However, despite these positive steps, there remain significant differences between countries regarding both the degree of change they have achieved and their timetables for reaching net-zero emissions. As of the year 2020, there is insufficient evidence to suggest that the world will meet the climate targets set by the Paris Agreement of 2016. According to (The Economist, 2020), to restrict climate change within the next 30-50 years period, there is a need to change the world power production mix in favor of $90 \%$ through renewable energy, with only the remaining $10 \%$ coming from non-renewable sources.

It is essential to mention that the shift towards renewable energy is not solely motivated by environmental concerns. Renewable energy is also attractive because it provides a potential means of industrial diversification and technology transfer (Kahia, Aissa, \& Safouane, 2014). Oilimporting countries face high levels of risks due to their dependence on imported non-renewable energy. Because the supply of these non-renewable resources (in particular, oil) is highly sensitive to national and international political disruptions, monopolistic behavior, and political instability (Huntington, 2009). Oil-importing countries could minimize these risks by increasing the renewable energy share in their national energy mix. However, despite the attractiveness of renewable energy, its production is restricted by various factors, not least of which are each country's geographic and climatic characteristics (Akar, 2016). Countries that lack plentiful suitable natural resources, such as strong winds, waterfalls, or solar irradiation, are less competitive 
in renewable energy investment ((Stadelmann \& Castro, 2014); (Aguirre \& Ibikunle, 2014); (Carley, 2009); (Bird, et al., 2005)). There have been scholarly studies focused on the determinants of renewable energy production, but these have mostly investigated the absolute value of renewable energy production in particular geographical regions. Little research has been undertaken to study renewable energy determinants in emerging and developed economies together ((Omri \& Nguyen, 2014); (Xu, Wei, Ji, Wang, \& Gao, 2019); (Seetharaman, Moorthy, Patwa, Saravanan, \& Gupta, 2019); (Soytas \& Sari, 2003)). Therefore, this study aims to present novel empirical evidence to determine renewable energy production elasticity from 26 countries (10 developed and 16 emerging countries), using data covering the period 1976 to 2018 . The study results will inform and guide governments on the right policies to stimulate renewable energy production in their own countries in the interests of both their national security and sustainable development globally.

The rest of the study is structured as follows: Section 2 is a literature review. The study's research methodology and the data used in the study, results, and discussion on the results are presented in Section 3, 4, and 5, respectively. Section 6 concludes the study with policy recommendations.

\section{LITERATURE REVIEW}

Research on the determinants of renewable energy production has become a popular area of study over recent decades. This increased attention on the emerging renewable energy sector is attributed to many catalysts, including political factors, the environmental consequence of $\mathrm{CO}_{2}$ emissions, and the volatility of oil prices (Apergis \& Payne, 2012). Several factors in a country may determine the size of renewable energy production as discussed subsequently ((Marques, Fuinhas, \& Manso, 2010); (Aguirre \& Ibikunle, 2014)).

Political motivation, determination, and actions are vital prerequisites for renewable energy production (Carley, 2009). It is challenging to replace traditional energy with renewable energy without first setting up an appropriate policy framework to mitigate the costs associated with switching to a sustainable system. (Aguirre \& Ibikunle, 2014) and (Polzin, Migendt, Täubec, \& von Flotow, 2015) discussed the need for long-term policy objectives and reliable frameworks. Both international and domestic political institutions influence renewable energy frameworks (Stadelmann \& Castro, 2014) and shape policy outcomes directly and indirectly.

The Kyoto Protocol of 1997 was one of the initial global policies aimed at reducing greenhouse gas emissions and promoting renewable energy production. This protocol was a major factor driving growth in renewable energy production across various countries (( Da Silva, Cerqueira, \& Ogbe, 2018); (Popp, Hascic, \& Medhi, 2011)). Similarly, global or regional institutions like the United Nations, the European Union, and the African Union set targets for reducing greenhouse gas emissions and increasing renewable energy production. Consequently, member countries of these institutions are more motivated to enhance renewable energy production.

Domestic supportive public policies, such as quotas, research, development, subsidies, feed-in tariffs, direct investment, and green certificates, can also stimulate renewable energy production (Marques \& Fuinhas, 2012). From an energy security perspective, the size of renewable energy production could be motivated by a desire to diversify the sources and origins of energy in the interests of reducing risks to national security ((Augutis, Martišauskas, Krikštolaitis, \& Augutienè, 2014); (Francés, Marín-Quemada, \& Gonzáleza, 2013)). (Chien \& Hub, 2008) investigated the direct and indirect effects of substituting renewable energy for traditional energy 
on trade balance and energy security. Energy importing countries require higher renewable energy deployment to guarantee their energy security (Aguirre \& Ibikunle, 2014). Policy design features vary in size, structure, administration, application, and eligibility. Therefore, we can expect different amounts of renewable energy production in each country.

Countries' market structures, regulations, and risk factors also impact renewable energy production (Siddiqui, Tanaka, \& Chen, 2016). Venture capital investors will avoid the renewable energy sector if regulatory exposure is perceived to be high (Chassot, Hampl, \& Wüstenhagen, 2014), assuming that they prefer a "free market" over government intervention. (Nesta, Vona, \& Nicolli, 2014) found that a "free market" has a significant impact on renewable energy development. The production of renewable energy is typically decentralized in small units, while traditional energy production is usually the preserve of large fossil fuel plants. Hence, market liberalization allows small-sized and non-utility energy generators to increase the incentives for renewable energy production.

In terms of technological drivers, $R \& D$ investment is a crucial factor in renewable energy production (Zhao, Chen, \& Li, 2019). R\&D can ensure a competitive, cost-effective renewable energy supply (Cho, Yang, Chu, \& Yang, 2013), thereby encouraging more renewable energy production. (Popp, Hascic, \& Medhi, 2011) investigated renewable energy investment across OECD countries from 1991 to 2004. They concluded that technological advancement increases investment in the renewable energy sector.

It is also important to consider that each country has its local context of socioeconomic factors. The existing scholarly literature has discussed the role of gross domestic product (GDP) growth, employment, conventional energy prices, and greenhouse gas emissions on the development of the renewable energy sector. A country with high GDP has the potential to deploy more renewable energy sources (Sadorsky, 2009). Higher-income OECD countries can respond to energy price changes by altering their use of renewable energy. In contrast, low-income countries typically remain unresponsive ( (Chang, Huang, \& Lee, 2009); (Gan, Eskeland, \& Kolshus, 2007)). Likewise, (Abanda, Ng'ombe, Keivani, \& Tah, 2012) reported a positive correlation between GDP and renewable energy production in African countries. Similar results were reported in Iran (Yazdi \& Shakouri, 2017) and for the long-term relationship between renewable energy production per capita and GDP per capita (Apergis \& Payne, 2011).

Lower employment opportunities may also trigger more investment in renewable energy. (Przychodzen \& Przychodzen, 2020) reported this relationship in 27 transition economies from Central and Eastern Europe and the Caucasus and Central Asia over 1990-2014. Similarly, (Igliński, Iglińska, Cichosz, Kujawski, \& Buczkowski, 2016) concluded that high unemployment positively impacted the advancement of renewable energy sources in Poland. (Hillebrand, Buttermann, Behringer, \& Bleuel, 2006) predicted that additional investment in renewable energy in Germany in 2006 would create 33,000 new jobs. Similarly, (Dvořák, Martinát, Vander Horst, Frantál, \& Turečková, 2017) identified the potential of investment in renewables to create new employment opportunities in a sector that employed 20,000 people in the Czech Republic in 2010.

The other significant factor that pushes countries to adopt renewable energy is their concerns regarding greenhouse gases emissions. Since $\mathrm{CO}_{2}$ has the most significant environmental impact of all of the greenhouse gases, the primary driver for G7 countries to increase their deployment of renewable energy is to reduce $\mathrm{CO}_{2}$ emissions (Sadorsky, 2009). Besides, (Marques, Fuinhas, \& Manso, 2010) and (Aguirre \& Ibikunle, 2014) also emphasized $\mathrm{CO}_{2}$ emission reduction as the most significant indicator of renewable energy deployment for the BRICS (Brazil, Russia, India, China, and South Africa) countries (1990-2006) and European countries (1990-2010). The 
production of renewable energy is likely to increase in line with additional concern about global warming.

The price of energy from traditional sources such as fossil fuels also affects the production and use of renewable energy. (Reboredo, 2015) found that high oil prices encourage the development of the renewable energy sector. (Sadorsky, 2009) and (Omri \& Nguyen, 2014) showed that the increment of oil prices has a small and negative correlation with renewable energy consumption. Yet, the exact nature of the relationship between oil prices and renewable energy production has not been confirmed, as it heavily depends on whether the country is oil-exporting or importing. (Bento \& Moutinho, 2016) found a cointegration between per capita renewable energy production and per capita $\mathrm{CO}_{2}$ emissions for Italy from 1960 to 2011. Furthermore, (Dogan \& Seker, 2016) found causality between $\mathrm{CO}_{2}$ emissions and renewable energy production for European countries from 1980 to 2012.

The other interesting aspect of renewable energy concerns the role of choices in the maximization of its usage, i.e., the use of the rational choice theory (RCT) of Cesare Beccaria. (Moran, 1996) asserted that RCT is an underlying theory for renewable energy whose assumptions are quite supportive in observing and designing the choice-related concerns for energy consumption to boost its economic value. (Cornish \& Clarke, 1987) argued that RCT supports making rational decisions to obtain a rational choice in the context of renewable energy. Also, renewable energy is significant in developing economic growth (Apergis \& Payne, 2010).

From the above discussion, it is clear that the factors that determine the likelihood of countries substituting existing traditional energy sources with renewable ones are many and complex. The current study focuses on the role of socioeconomic factors. Most of the previous research in this field has focused only on the absolute value of renewable energy production in a particular geographical area. Little research has been conducted on emerging and developed countries together. Based on this omission, the literature failed to identify common determining factors in both emerging and advanced economies. This study attempts to fill this gap with a particular focus on the socioeconomic factors which determine the extent to which countries shift to renewable energy production.

\section{DATA AND RESEARCH METHODOLOGY}

\subsection{Data}

This study is based on annual data from 26 countries covering the period from 1976 till 2018. These countries are Australia, Bangladesh, Brazil, Canada, China, Denmark, Egypt, Germany, India, Indonesia, Iran, Malaysia, Mexico, Netherlands, New Zealand, Norway, Pakistan, Philippines, Russia, Singapore, South Africa, South Korea, Switzerland, Turkey, the U.S., and Vietnam. The study sample includes ten developed and 16 emerging countries.

The emerging economies covered in the study are a combination of the BRICS countries plus ten of the Next Eleven (N-11). The N-11 countries have the potential to become the world's largest economies in the 21 st century. Jim O'Neill, the economist who coined the acronym BRIC also identified the N-11 countries. The only one of the N-11 not included in this study is Nigeria because its data was not available for the entire 1976 to 2018 period. Additionally, the sample also includes Malaysia (a non-N-11 country), a developing economy with a focus on renewable energy (Haseeb, Abidin, Hye, \& Hartani, 2019). Finally, a small number of missing data points across the study as a whole were predicted using a simple linear regression technique with a standard error of 0.031 and a 95 percent confidence interval. 
This study uses several variables in the analysis; accordingly, we obtained data for these variables from several sources. The data on real GDP per capita data was obtained from the United Nations (UN) National Accounts Database (UN, 2019). The National Accounts database of the UN covers over 200 countries from the period of 1970 until recent years and is updated every year in December. Data is collected through the UN Statistics Division from member countries; in case of any missing official data, other data sources are analyzed to gather supplementary data, estimation procedures are applied for the entire time series (UN, 2019).

The data on renewable energy production (including geothermal, solar, tides, wind, biomass, and biofuels) were obtained from the Organization for Economic Co-operation and Development (OECD) database (OECD, 2019). This database contains data on renewable energy production as a total percentage of primary energy supply covering the period from 1960 till 2019 for all the countries in our sample. The information on $\mathrm{CO}_{2}$ emissions for all the sampled countries was obtained from British Petroleum Statistical Review (BP, 2019). Finally, oil prices were obtained from the West Texas Intermediate crude oil spot prices because these have a long history of being representative of world crude oil prices. In summary, the study uses four variables (real GDP per capita, renewable energy as a percentage of total energy, $\mathrm{CO}_{2}$ emissions, and oil prices) for 26 countries from 1976 till 2018.

The descriptive statistics of all variables for both groups, i.e., all countries together and separate groups each for developed countries and emerging countries, are presented in Table 1. The total observations from 26 countries are 1,118, out of which 688 observations are from 16 emerging countries, and 430 are from 10 developed countries. It can be observed from Table 1, that the average GDP per capita across all 26 countries is US\$ 14,392. In contrast, the ten developed countries have about 120 percent (US\$ 31,868) higher per capita income compared to the entire 26 countries. In contrary, the 16 emerging countries have per capita income equal to US\$3,469, which is about 76 per cent lower than that of the average per capita GDP of all 26 countries. The average energy production from renewable sources for all 26 countries was 32,255 megawatts.

Furthermore, the ten developed countries had an average of 40.12 percent less renewable output than the average production of all 26 countries. On the other hand, the 16 emerging countries produced 25.07 percent more renewable energy than the average renewable output of all 26 countries. This is consistent with the fact that recently much of the growth in renewable energy has come from developing countries (Seetharaman, Moorthy, Patwa, Saravanan, \& Gupta, 2019); (Sadorsky, 2009)). Furthermore, increases in economic growth in emerging countries gives these countries a chance to increase their usage of renewable energy (Sadorsky, 2009).

The $\mathrm{CO}_{2}$ emissions in developed countries are about 14 percent higher than the average $\mathrm{CO}_{2}$ emissions of 26 countries, whereas, for emerging countries, these $\mathrm{CO}_{2}$ emissions are about 9 percent lower than the average of 26 countries. These numbers are consistent with the existing literature that claims that historically developed countries contributed most $\mathrm{CO}_{2}$ emissions (Wei, et al., 2012); (Den Elzen, Olivier, Höhne, \& Janssens-Maenhout, 2013)).

Table 1 Descriptive Statistics

$\underline{\text { Variables }} \quad \underline{\text { Observations }} \quad \underline{\text { Mean }} \quad \underline{\text { Standard deviation }} \quad \underline{\text { Minimum }}$ Maximum




\begin{tabular}{|c|c|c|c|c|c|}
\hline \multicolumn{6}{|c|}{10 developed countries } \\
\hline Renew & 430 & 19314.7 & 32966.9 & 0.00 & 172390.0 \\
\hline GDP & 430 & 31868.1 & 20385.5 & 2649.5 & 102830.0 \\
\hline $\mathrm{CO}_{2}$ & 430 & 757.0 & 1573.1 & 19.0 & 6132.4 \\
\hline Oil price & 430 & 39.8 & 26.6 & 12.2 & 100.1 \\
\hline \multicolumn{6}{|c|}{$\underline{16 \text { emerging countries }}$} \\
\hline Renew & 688 & 40343.0 & 64342.4 & 470.1 & 342880.0 \\
\hline GDP & 688 & 3468.9 & 4492.8 & 33.9 & 33622.0 \\
\hline $\mathrm{CO}_{2}$ & 688 & 603.7 & 1298.4 & 5.1 & 9428.7 \\
\hline Oil price & 688 & 39.8 & 26.6 & 12.2 & 100.1 \\
\hline \multicolumn{6}{|c|}{ All 26 countries } \\
\hline Renew & 1118 & 32255.2 & 55393.1 & 0.0 & 342880.0 \\
\hline GDP & 1118 & 14391.1 & 19054.7 & 33.9 & 102830.0 \\
\hline $\mathrm{CO}_{2}$ & 1118 & 662.7 & 1411.7 & 5.1 & 9428.7 \\
\hline Oil price & 1118 & 39.8 & 26.6 & 12.2 & 100.1 \\
\hline
\end{tabular}

\subsection{Research Methodology}

To fulfill the objectives of this study, we conducted panel data and time-series analyses to identify panel and country-specific elasticity of renewable energy production in terms of income, $\mathrm{CO}_{2}$ emissions, and oil prices, as well as the dynamic causal relationships among the variables. The long-run elasticities were identified by applying the panel cointegration techniques of Pedroni (Pedroni, 2001). This technique can be used after ensuring that the data are non-stationary time series (Choi, 2006). Besides, many studies concluded that there is no stationarity in time series data (Leybourne, McCabe, \& Tremayne, 1996); (Smith, 2000)). The data was be checked for stationarity using panel unit root tests before applying panel cointegration techniques ((Shrestha \& Bhatta, 2018); (Kurths \& Pikovsky, 1998)).

Furthermore, the descriptive statistics of data were checked to investigate the potential determining factors of renewable energy production in developed and emerging countries. We also applied fully modified ordinary least square (FMOLS) and parametric dynamic ordinary least square (DOLS) techniques to investigate the possible elasticity of renewable energy in terms of the exogenous variables. The use of the FMOLS approach solved the problems arising from endogeneity and serial correlation in the typical ordinary least square (OLS) estimator. (Pedroni, 2001) proposed a DOLS estimator that parametrically eliminates the endogeneity and serial correlation problems. Moreover, endorsing (Farahani, Rahiminezhad, \& Same, 2010) the ordinary least square (OLS) technique is also used to develop and infer the unbiased estimators often influenced by the serial correlation.

\section{Econometric Modeling}

Before estimating the long-run and short-run relationships among the variables of interest, the existence of relationships was confirmed using Pedroni's panel cointegration tests and Kao's cointegration test. For this purpose, the autoregressive distributed lag model (ARDL) can be employed after confirming if it is the most appropriate model to use (Pesaran, Shin, \& Smith, 2001). ARDL avoids the inherent limitations in testing for unit roots before testing for 
cointegration and can be conveniently applied to studies that have a small sample size. ${ }^{1}$ The basic idea of the ARDL approach is to test for the existence of long-term relationships among the variables in the model. The ARDL model is used extensively in the scholarly literature ((Guy, 2008); (Shahbaz \& Lean, Does Financial Development Increase Energy Consumption? The Role of Industrialization and Urbanization in Tunisia, 2012) (Shahbaz, Adnan, Tiwari, \& Leitão, 2013); (Sunde, 2017)).

In our study, the test involved estimating the following unrestricted error correction model (UECM) considering each variable in turn as a dependent variable: ${ }^{2}$

$$
\Delta \Re_{t}=\beta_{0}+\sum_{i=1}^{m} \beta_{i t} \Delta G D P_{t-i}+\sum_{j=0}^{n} \beta_{2 j} \Delta C O_{2_{t-j}}+\sum_{k=0}^{o} \beta_{3 k} \Delta O P_{t-k}+\beta_{3} G D P_{t-1}+\beta_{4} C O_{2 t-1}
$$

where $\Re_{t}, G D P_{t}, C O_{2 t}$ and $O P_{t}$ are renewable energy production, gross domestic product, carbon emission, and oil price, respectively. $\varepsilon_{t}$ is assumed to be white noise 'well-behaved' random disturbance term. The null hypothesis of 'no-long-run relation' can be tested through $F$ or $\chi^{2}$ test of the joint significance of the lagged level coefficients. Short-run dynamics or causality are tested through the significance of differenced terms. (Pesaran, Shin, \& Smith, 2001) demonstrate that the distribution of the test statistics $\left(F\right.$ or $\left.\chi^{2}\right)$ is non-standard irrespective of whether the regressors are $I(0)$ or $I(1)$.

Finally, we also wanted to study the causal relationship between our variables of interest. The Granger causality test model for time series data was introduced by Granger (1969) (Gujarati, 2011). Its basic idea is that if a variable $X_{t}$ can be predicted by the past usage value of the variable $Y_{t}$ with greater accuracy, we can say $X_{t}$ is caused by $\mathrm{Y}_{\mathrm{t}}$. The Granger causality test is dependent upon the Vector autoregression (VAR) model. The first step of the Granger causality test may be calculated using the VAR model, as presented in Equation (2) and Equation (3):

$$
\begin{gathered}
Y_{t}=\alpha_{1}+\sum_{i=1}^{n} \beta_{i} X_{t-i}+\sum_{j=1}^{m} \mu_{j} Y_{t-j}+\varepsilon_{1 t} \\
X_{t}=\alpha_{2}+\sum_{i=1}^{n} \partial_{i} X_{t-i}+\sum_{j=1}^{m} \omega_{j} Y_{t-j}+\varepsilon_{2 t}
\end{gathered}
$$

Here, $\varepsilon_{1 t}$ and $\varepsilon_{2 t}$ are termed as uncorrelated white noise expressions. In this Granger test model, there are following four different possibilities between the casualty of $X_{t}$ and $Y_{t}$ as detailed below. First, $X_{t}$ is caused by $Y_{t}$ (when there is a difference between zero and lagged $X$ term in Equation (3), and no difference between zero and lagged $Y$ term in Equation (2)). Second, $Y_{t}$ is caused by

\footnotetext{
${ }^{1}$ Unlike traditional unit root and cointegration tests which are known to have low power and size properties in small samples.

${ }^{2}$ It's called unrestricted because all the long run relationship' variables are specified. So, there is no restriction about the presence of any variables. So, when you replace this long run relationship by its Residuals, the model becomes ECM because the ECT (Error Correction Term) corrects the disequilibrium happened in a short period, by bringing the situation to a steady statement.
} 
$X_{t}$ (when there is a difference between zero and lagged $Y$ term in Equation (2), and no difference between zero and lagged $X$ term in Equation (3)). Third, there is bi-directional causality (when there is a difference between both lagged $Y$ and lagged $X$ term with zero in Equation (2) and (3), respectively). Finally, $Y_{t}$ is dependent on $X_{t}$ (when there is no difference between both lagged $Y$ and lagged $X$ terms with zero in Equation (1) and (2), respectively).

\section{RESULTS AND FINDINGS}

\subsection{Preliminary analysis}

We converted the sample data into a panel data format because the study uses a panel model. Panel data provides more information, with less collinearity between variables, therefore making them more efficient in the estimation, with a higher degree of freedom, and more significant variability of data ((Greene, 2003);(Marques, Fuinhas, \& Manso, 2010))

The data stationarity was checked using panel unit root tests, the results of which are presented in Table 2. We used all variables in logarithmic form, with automatic lag selection and used Schwarz information criteria. Since the oil price (OP) was the same among all the individual countries, we employed simple unit root tests for time series data. The results of these tests are presented in Table 3. The results from Table 2 and Table 3 show that renewable energy production (RE), GDP per capita (GDP), and $\mathrm{CO}_{2}$, and also OP are I(1), implying satisfactory conditions for a cointegration test.

Table 2. Panel unit root test

\begin{tabular}{|c|c|c|}
\hline - & Im-Pesaran-Shin, W-t-bar & Fisher-type inverse chi-squared \\
\hline $\mathrm{RE}$ & 10.89 & 18.65 \\
\hline$\Delta \mathrm{RE}$ & $-14.56^{*}$ & $855.40^{*}$ \\
\hline GDP & 9.93 & 6.52 \\
\hline$\Delta \mathrm{GDP}$ & $-14.51 *$ & $520.08^{*}$ \\
\hline $\mathrm{CO}_{2}$ & 10.53 & 15.20 \\
\hline$\Delta \mathrm{CO}_{2}$ & $-13.42 *$ & $783.10^{*}$ \\
\hline
\end{tabular}

* Significant at $1 \%$

Table 3. Simple unit root test

\begin{tabular}{|r|c|c|c|}
\hline & ADF & PP & KPSS \\
\hline OP & -3.641 & -3.634 & 0.134 \\
\hline$\Delta$ OP & $-3.648^{*}$ & $-3.641^{*}$ & $0.108^{*}$ \\
\hline
\end{tabular}

* Significant at $1 \%$

We applied a panel cointegration test (Pedroni, 2001) for our variables of interest to confirm the presence of cointegration (before estimating the long-run and short-run relationships). The values of seven statistics for (Pedroni, 2001) test and its statistics and p-values are given in the upper portion of Table 4. The results include four-panel tests, each with two results (statistics and weighted statistics) and their respective p-values. Also, among the three groups' statistics, only one is statistically significant. Finally, 6 test statistics of the (Pedroni, 2001) test (in total 11) show statistical significance implying the presences of long-run cointegration between all variables. We 
also applied Kao's cointegration test to confirm the presence of cointegration further. Kao's cointegration test (lower portion of Table 4) also confirmed the presences of a long-run cointegration among all the variables.

Table 4 Cointegration tests results

\begin{tabular}{|c|c|c|c|c|}
\hline \multicolumn{5}{|c|}{ Pedroni's cointegration test } \\
\hline Test & statistic & p-value & weighted statistic & p-value \\
\hline Panel v-Statistic & -1.54 & 0.939 & $2.69 *$ & 0.004 \\
\hline Panel rho-Statistic & $-2.56^{*}$ & 0.005 & 0.08 & 0.533 \\
\hline Panel PP-Statistic & $-5.19 *$ & 0.000 & -1.73 & 0.041 \\
\hline Panel ADF-Statistic & $-5.25^{*}$ & 0.000 & $-2.59 *$ & 0.005 \\
\hline Group rho-Statistic & 1.04 & 0.851 & & \\
\hline Group PP-Statistic & -1.45 & 0.073 & & \\
\hline Group ADF-Statistic & $-2.54 *$ & 0.006 & & \\
\hline \multicolumn{5}{|c|}{ Kao's Cointegration Test } \\
\hline t-sta & \multirow{2}{*}{$\begin{array}{c}\text { t-statistic } \\
2.99^{*}\end{array}$} & value & Resi. Var. & C Var. \\
\hline $\mathrm{ADF}$ & & 001 & 12934204 & 62530 \\
\hline
\end{tabular}

* Significant at $1 \%$

\subsection{Nexus between renewable energy production and socioeconomic conditions}

To identify the long-run relationships among the variables, we first applied group-means fully modified OLS (FMOLS) to solve the problem that may arise from endogeneity and serial correlation of OLS estimators. Besides, we also implemented parametric dynamic OLS (DOLS) that parametrically eliminated the endogeneity and serial correlation problems (Pedroni, 2001). The estimates of long-run elasticities produced by the FMOLS and DOLS techniques of equation (1) are presented in Table 5.

The dependent variable is renewable energy (RE), whereas the independent variables are GDP, $\mathrm{CO}_{2}$, and OP. The results are presented for the entire sample of 26 countries, and also separately in groups for developing and emerging countries. The lower portion of Table 5 shows the FMOLS and DOLS results for each country separately.

Table 5 FMOLS and DOLS results (dependent variable: renewable energy)

\begin{tabular}{|c|c|c|c|}
\hline & & FMOLS & DOLS \\
\hline Countries & $\begin{array}{r}\text { Independent } \\
\text { variables }\end{array}$ & Coefficient (S.E) & Coefficient (S.E) \\
\hline \multirow{3}{*}{ All countries } & GDP & $-1.52 * * * \quad(0.20)$ & $-1.41 * * *$ \\
\hline & $\mathrm{CO}_{2}$ & $26.55 * * * \quad(5.00)$ & $26.23 * * *$ \\
\hline & OP & $(10.60)$ & -23.26 \\
\hline \multirow{3}{*}{ Developed countries } & GDP & $0.32 * * * \quad(0.04)$ & $0.32 * * *$ \\
\hline & $\mathrm{CO}_{2}$ & $-27.62 * * \quad(10.90)$ & $-26.14 * *$ \\
\hline & OP & $(12.02)$ & $(14.27)$ \\
\hline \multirow{3}{*}{$\begin{array}{l}\text { Emerging } \\
\text { countries }\end{array}$} & GDP & $-2.68 * * *(0.40)$ & $-2.50 * * *$ \\
\hline & $\mathrm{CO}_{2}$ & $60.42 * * *(4.40)$ & $58.96 * * *$ \\
\hline & OP & $(15.50)$ & -38.05 \\
\hline
\end{tabular}




\begin{tabular}{|c|c|c|c|c|}
\hline \multicolumn{5}{|c|}{ Developed Countries } \\
\hline \multirow{3}{*}{ Australia } & GDP & $0.06^{* * *}(0.02)$ & 0.04 & $(0.03)$ \\
\hline & $\mathrm{CO}_{2}$ & $5.66^{*} \quad(3.19)$ & $8.33 *$ & $(4.27)$ \\
\hline & OP & -15.99 & -9.63 & $(16.36)$ \\
\hline \multirow{3}{*}{ Canada } & GDP & $0.64 * * *(0.10)$ & $0.61 * * *$ & $(0.12)$ \\
\hline & $\mathrm{CO}_{2}$ & $34.72 * * \quad(14.70)$ & $37.54 * *$ & $(15.40)$ \\
\hline & $\mathrm{OP}$ & $-172.66^{* * *}(39.30)$ & $-181.23 * * *$ & $(54.70)$ \\
\hline \multirow{3}{*}{ Denmark } & GDP & $0.06^{* * *}(0.01)$ & $0.06 * * *$ & $(0.007)$ \\
\hline & $\mathrm{CO}_{2}$ & $-91.73 * * *(10.07)$ & $-84.40 * * *$ & $(12.80)$ \\
\hline & OP & $-9.61 * *(5.08)$ & -7.98 & $(5.70)$ \\
\hline \multirow{3}{*}{ Germany } & GDP & $(0.40)$ & 0.11 & $(0.40)$ \\
\hline & $\mathrm{CO}_{2}$ & -38.99 & -21.17 & $(46.20)$ \\
\hline & $\mathrm{OP}$ & $252.50 * * \quad(97.70)$ & $273.23 * * *$ & $(76.40)$ \\
\hline \multirow{3}{*}{ Netherlands } & GDP & $0.10 * * *(0.01)$ & $0.11 * * *$ & $(0.01)$ \\
\hline & $\mathrm{CO}_{2}$ & $-13.82 * * \quad(5.30)$ & -12.30 & $(7.40)$ \\
\hline & $\mathrm{OP}$ & $-\quad 5.53$ & -7.31 & $(7.01)$ \\
\hline \multirow{3}{*}{ New Zealand } & GDP & $0.17 * * *(0.015)$ & $0.16 * * *$ & $(0.02)$ \\
\hline & $\mathrm{CO}_{2}$ & $(23.23)$ & 8.72 & $(25.20)$ \\
\hline & $\mathrm{OP}$ & $-16.07 * * *(5.04)$ & $-15.27 * *$ & $(6.90)$ \\
\hline \multirow{3}{*}{ Norway } & GDP & $0.13 * * *(0.02)$ & $0.13 * * *$ & $(0.02)$ \\
\hline & $\mathrm{CO}_{2}$ & $-130.92 \quad(96.15)$ & -127.10 & $(99.20)$ \\
\hline & $\mathrm{OP}$ & $-89.26^{* * *}(20.30)$ & $-96.90 * * *$ & $(21.80)$ \\
\hline \multirow{3}{*}{ Singapore } & GDP & $0.002 \quad(0.002)$ & -0.004 & $(0.004)$ \\
\hline & $\mathrm{CO}_{2}$ & $1.60 * *(0.75)$ & $3.22 * *$ & $(1.30)$ \\
\hline & $\mathrm{OP}$ & $-\quad 0.11$ & 0.26 & $(0.50)$ \\
\hline \multirow{3}{*}{ Switzerland } & GDP & $0.03 * * *(0.004)$ & $0.03 * * *$ & $(0.005)$ \\
\hline & $\mathrm{CO}_{2}$ & -16.20 & 37.64 & $(49.60)$ \\
\hline & $\mathrm{OP}$ & $-6.33^{*}(3.70)$ & -0.61 & $(5.40)$ \\
\hline \multirow{3}{*}{ United States } & GDP & $1.89 * * *(0.13)$ & $1.93 * * *$ & $(0.30)$ \\
\hline & $\mathrm{CO}_{2}$ & $-29.96 * * *(3.27)$ & $-34.02 * * *$ & $(6.30)$ \\
\hline & $\mathrm{OP}$ & $-\quad 5.93$ & 44.76 & $(117.60)$ \\
\hline \multicolumn{5}{|c|}{ Emerging Countries } \\
\hline \multirow{3}{*}{ Bangladesh } & GDP & $-3.80 * * *(0.84)$ & $-\quad 3.37^{*}$ & $(1.74)$ \\
\hline & $\mathrm{CO}_{2}$ & $116.54 * * *(15.59)$ & $120.89 * * *$ & $(26.09)$ \\
\hline & $\mathrm{OP}$ & $-9.20 * \quad(4.88)$ & -9.48 & $(6.95)$ \\
\hline \multirow{3}{*}{ Brazil } & GDP & $(1.22)$ & $-\quad 0.71$ & $(1.94)$ \\
\hline & $\mathrm{CO}_{2}$ & $193.30 * * *(32.70)$ & $199.64 * * *$ & $(47.80)$ \\
\hline & $\mathrm{OP}$ & $(99.30)$ & 207.27 & $(130.40)$ \\
\hline \multirow{3}{*}{ China } & GDP & $-\quad 5.34$ & $-\quad 1.97$ & $(4.50)$ \\
\hline & $\mathrm{CO}_{2}$ & $15.57 * * *(3.80)$ & 8.85 & $(5.20)$ \\
\hline & $\mathrm{OP}$ & $(226.00)$ & $-698.13^{*}$ & $(361.50)$ \\
\hline \multirow{3}{*}{ Egypt } & GDP & $(0.08)$ & 0.156 & $(0.10)$ \\
\hline & $\mathrm{CO}_{2}$ & $10.26^{* * *}(1.30)$ & $9.051 * * *$ & $(1.50)$ \\
\hline & OP & $-3.97 * *(1.70)$ & $-\quad 6.90 * * *$ & $(2.10)$ \\
\hline \multirow{3}{*}{ India } & GDP & $-27.88 * * *(5.50)$ & $-28.30 * * *$ & $(7.30)$ \\
\hline & $\mathrm{CO}_{2}$ & $61.64 * * *(4.40)$ & $57.80 * * *$ & $(4.80)$ \\
\hline & $\mathrm{OP}$ & $230.74 * * *(40.70)$ & $189.02 * *$ & $(72.80)$ \\
\hline \multirow{2}{*}{ Indonesia } & GDP & $-4.22 * * \quad(1.92)$ & $-\quad 3.73$ & $(2.46)$ \\
\hline & $\mathrm{CO}_{2}$ & $130.50 * * *(12.10)$ & $132.13 * * *$ & $(11.20)$ \\
\hline
\end{tabular}




\begin{tabular}{|c|c|c|c|}
\hline & OP & -67.60 & $-152.51 * * \quad(66.70)$ \\
\hline \multirow{3}{*}{ Iran } & GDP & $(0.04)$ & $0.02 * * \quad(0.25)$ \\
\hline & $\mathrm{CO}_{2}$ & $1.78 * * *(1.70)$ & $(0.84)$ \\
\hline & $\mathrm{OP}$ & $(1.30)$ & $(17.60)$ \\
\hline \multirow{3}{*}{ Malaysia } & GDP & $0.24 * * *(0.06)$ & $0.17 * * *(0.05)$ \\
\hline & $\mathrm{CO}_{2}$ & $(2.20)$ & $(2.02)$ \\
\hline & $\mathrm{OP}$ & $-17.66 * * *(3.50)$ & $-18.50 * * *(3.40)$ \\
\hline \multirow{3}{*}{ Mexico } & GDP & $-\quad 2.43$ & $-\quad 4.76$ \\
\hline & $\mathrm{CO}_{2}$ & $88.143^{* *}(40.30)$ & $127.71 * * \quad(52.70)$ \\
\hline & $\mathrm{OP}$ & $-4.63 \quad(20.20)$ & $-72.10^{* *} \quad(27.30)$ \\
\hline \multirow{3}{*}{ Pakistan } & GDP & $(1.30)$ & $(1.80)$ \\
\hline & $\mathrm{CO}_{2}$ & $131.48 * * *(8.20)$ & $133.10 * * *(8.50)$ \\
\hline & $\mathrm{OP}$ & $-32.73 * * *(9.70)$ & $-42.31 * * *(13.40)$ \\
\hline \multirow{3}{*}{ Philippines } & GDP & $-\quad 2.11$ & $-\quad 2.82$ \\
\hline & $\mathrm{CO}_{2}$ & $105.52 * * \quad(46.50)$ & $(49.90)$ \\
\hline & $\mathrm{OP}$ & $(22.57)$ & $(65.40)$ \\
\hline \multirow{3}{*}{ Russia } & GDP & $(0.17)$ & $(0.10)$ \\
\hline & $\mathrm{CO}_{2}$ & $9.25 * * *(0.90)$ & $9.214 * * *(0.70)$ \\
\hline & $\mathrm{OP}$ & $53.07 * * \quad(26.10)$ & $66.53 * * \quad(28.70)$ \\
\hline \multirow{3}{*}{ South Africa } & GDP & $0.61 * \quad(0.30)$ & $(0.50)$ \\
\hline & $\mathrm{CO}_{2}$ & $38.11 * * *(4.90)$ & $39.01 * * *(5.70)$ \\
\hline & $\mathrm{OP}$ & $-44.42 * * *(14.90)$ & $-46.93^{* *}(20.90)$ \\
\hline \multirow{3}{*}{ South Korea } & GDP & $0.32 * * *(0.03)$ & $0.30 * * *(0.04)$ \\
\hline & $\mathrm{CO}_{2}$ & $-9.95 * * *(1.65)$ & $9.57 * * *(1.80)$ \\
\hline & $\mathrm{OP}$ & $-24.70 * * *(4.90)$ & $-23.95 * * *(5.50)$ \\
\hline \multirow{3}{*}{ Turkey } & GDP & $\begin{array}{lll}- & 0.02 \quad(0.40) \\
\end{array}$ & $(0.40)$ \\
\hline & $\mathrm{CO}_{2}$ & $26.96 * * *(9.60)$ & $(9.32)$ \\
\hline & $\mathrm{OP}$ & $-36.62 \quad(22.65)$ & $-\quad 32.36$ \\
\hline \multirow{3}{*}{ Vietnam } & GDP & -2.43 & -4.76 \\
\hline & $\mathrm{CO}_{2}$ & $88.14 * * \quad(40.30)$ & $127.71 * * \quad(52.70)$ \\
\hline & OP & -4.63 & $-72.10 * *(27.40)$ \\
\hline
\end{tabular}

\section{Results of the group of countries}

It is essential to mention that two methods, DMOLS and FMOLS, were applied in the analysis. There is some minor deviation in terms of statistical significance and size of the coefficients from the results of the two methods. However, the results are comparable across both processes.

The results indicate the different direction of elasticities for the two groups of countries. It is interesting to observe that the coefficients of GDP are negative for the emerging countries (showing a negative relationship between GDP per capita and renewable energy) and positive for the developed countries (indicating a positive relationship between GDP per capita and renewable energy). These are plausible findings and are consistent with the earlier literature. For example, (Mohiuddin, Asumadu-Sarkodie, \& Obaidullah, 2016) reported similar relationship for RE, GDP and $\mathrm{CO}_{2}$ for emerging countries or, (Chien \& Hub, 2008) reporting a positive relationship between real consumption and biomass-made energy for US economy.

The coefficient of $\mathrm{CO}_{2}$ was significantly negative for developed countries and positive for emerging countries by both FMOLS and DOLS estimation. This is an interesting finding. It 
suggests a positive relationship between $\mathrm{RE}$ and $\mathrm{CO}_{2}$ for emerging countries but a negative relationship between these two variables for the developed countries. This may be attributed to the fact that the developed countries are self-sufficient in their energy production. Therefore, when adding additional energy production capacity, they are more likely to be focused on RE (because for them it is not about meeting minimum energy demands), so it is obvious to find a negative relationship between $\mathrm{CO}_{2}$ and $\mathrm{RE}$. Another possible explanation is that there are more $\mathrm{CO} 2$ emissions in these countries, so they have to increase RE production to align themselves with emission reduction targets. In contrast, the emerging economies are still struggling to catch up to meet existing energy demands (a number of countries, such as India, Pakistan, are not able to meet their minimum energy demands and power outages are common in these countries). So, along with increasing their energy supplies through traditional non-renewable energy sources, these countries are also increasing their production of RE. Thus, $\mathrm{CO}_{2}$ and $\mathrm{RE}$ both may be establishing a positive relationship. Finally, the impact of oil prices on renewable energy production are not statistically significant for both developed and emerging economies.

Results of country-specific findings

The countries that had statistically significant results (by at least one of the methods) for the relationship between RE and GDP, mainly were positive except for Bangladesh, India, and Indonesia. The countries showing a positive relationship between GDP and $\mathrm{CO}_{2}$ (such as most of the developed countries and some emerging economies like Malaysia and Turkey) could be attributed to the job creation and economic prospects associated with the development of the newer (RE) energy sector (Al-Mulali, Fereidouni, Lee, \& Sab, 2013). The negative coefficients of $\mathrm{CO}_{2}$ (for Bangladesh, India, and Indonesia) may imply that these countries are still facing issues of increasing energy demand due to their growing economies and populations (Bhattacharya, Paramati, Ozturk, \& Bhattacharya, 2016), as these countries are among the most populated countries of the world.

The $\mathrm{RE}$ and $\mathrm{CO}_{2}$ relationship for six developed countries and fifteen emerging economies are statistically significant. The results show mainly the positive relationship between $\mathrm{RE}$ and $\mathrm{CO}_{2}$ (for all emerging countries (except South Korea) and also for some of the developed countries (Denmark, Netherlands, New Zealand, Norway, Switzerland, and the USA). The likely explanation for this finding is that although these countries were increasing their RE production in the study period, they also increased their non-renewable energy production. Therefore, RE was rising along with rises in $\mathrm{CO}_{2}$ within these countries. It may also be possible that some of these countries may be aiming for reducing $\mathrm{CO}_{2}$ by increasing their RE production to achieve their emissions reduction targets.

Finally, we found a statistically significant and positive relationship between RE and OP for China, India, and Russia, whereas for all other countries the relationship between these two variables were either statistically insignificant or negative. Oil is a substitute product to RE, so, if the prices of oil (i.e., OP) increase, one would expect that the demand (hence, production) of RE will increase because people switch to cheaper alternatives when the price of a product rises (Mankiw, 2019), this is a plausible finding for China and India, the two major oil importers in the world due to their higher energy demand. The positive relationship between RE and OP for these countries may imply their substitution from expensive oil to cheaper RE sources. However, this switching is not that easy because RE is not easy to adopt due to technological limitations, policy issues, and economies of scale (Shukla, Sudhakar, \& Baredar, 2017). The same explanation is not consistent for Russia where we also found a positive relationship between RE and OP. This may also be due to the higher flexibility of Russia as it also has enormous natural gas resources and 
hydropower. Thus, they may be possibly replacing expensive oil (selling it abroad at higher prices) with cheaper natural gas (available locally) and hydropower energy production. As the cross-price elasticity for complementary goods is negative (Mankiw, 2019), so having a negative relationship between RE and OP implies that in those countries RE is a "complementary good" rather than a "substitute good" for oil. In other words, these countries are meeting their energy demands by using oil along with RE and possibly all other available, but relatively cheap, energy sources.

\subsection{Long and short-run dynamics of renewable energy: ARDL results}

To find out the short and long-run dynamics (elasticities) of renewable energy with the other three variables, we applied ARDL using EViews with automatic lag selection as per the specification of Equation (1). The results of ARDL and the long and short-run dynamics are presented in Table 6 and Table 7 , respectively.

\section{Long-run dynamics}

The ARDL results for GDP and RE are consistent with that of the findings from FMOLS and DOLS for all three aggregate cases. The $\mathrm{RE}$ and $\mathrm{CO}_{2}$ relationship was also found to be positive at the aggregate level, but it was not statistically significant for the developed countries. Since emerging economies are still growing, and their energy production is increasing both from renewable and non-renewable (unlike developed countries that are more focused on increasing RE production), therefore, in emerging economies the positive relationship between $\mathrm{RE}$ and $\mathrm{CO}_{2}$ is not unexpected. Finally, the statistically significant long-run relationship between RE and OP for emerging countries shows a strong increase in RE production with an increase in OP. This implies that the production of renewable energy is oil price-sensitive in emerging countries. This also indicates that RE works as a substitute for oil in emerging economies.

At the country level, the long-run relationship among RE, GDP, $\mathrm{CO}_{2}$, and $\mathrm{OP}$ does not present a clear picture of the relationship dynamics. The relationship between RE and GDP was not statistically significant for most of the countries. In the cases where RE and GDP's long-run relationship was significant there were mixed findings. For instance, for the three highest emissions producing countries globally, i.e., the United States, China, and India, the RE and GDP relationship was positive (and significant). In contrast, for Denmark and Brazil, it was negative (and significant). For other countries in the sample, the relationship between RE and GDP was not statistically significant. A similar kind of pattern in the findings was visible for the long-run relationship of $\mathrm{RE}$ with $\mathrm{CO}_{2}$ and $\mathrm{OP}$. 
Table 6 ARDL results

\begin{tabular}{|c|c|c|c|c|c|c|}
\hline \multirow{3}{*}{$\begin{array}{l}\text { Country } \\
\text { All Countries } \\
\end{array}$} & \multicolumn{3}{|c|}{ LR } & \multicolumn{3}{|c|}{ SR } \\
\hline & GDP & $\mathrm{CO}_{2}$ & OP & $\Delta G D P$ & $\Delta \mathrm{CO}_{2}$ & $\Delta \mathrm{OP}$ \\
\hline & $-0.487 * *(0.26)$ & $40.131 * * * \quad(2.60)$ & $(15.96)$ & 3.778 & -14.920 & 12.131 \\
\hline Developed Countries & $0.162 * * *(0.02)$ & $(12.95)$ & -12.239 & -0.128 & $-37.291^{*}$ & $29.382 * \quad(16.75)$ \\
\hline Emerging Countries & $-1.287 * * *(0.15)$ & $42.062 * * * \quad(2.76)$ & $65.995 * * *(12.85)$ & 5.938 & $(8.72)$ & $(6.26)$ \\
\hline Australia & $(0.02)$ & -8.991 & $(7.05)$ & $(0.04)$ & $(9.89)$ & $-17.145^{*}(8.58)$ \\
\hline Canada & -0.270 & -8.701 & $107.021 * * *(37.30)$ & $(0.18)$ & -34.794 & -61.220 \\
\hline Denmark & $\mathbf{- 0 . 0 1 1} * * \quad(0.005)$ & $(5.69)$ & 4.064* & & & $-7.269 * * *(3.49)$ \\
\hline Germany & -0.038 & $-7.436 *$ & $(8.50)$ & & & \\
\hline Netherlands & $(0.17)$ & $(3.96)$ & -0.214 & 0.008 & -1.311 & $(2.40)$ \\
\hline New Zealand & $(0.01)$ & $-77.590 * *$ & $(3.60)$ & & $76.237 * * \quad(31.76)$ & -5.387 \\
\hline Norway & $(0.05)$ & $-\mathbf{3 1 5 . 7 0 6 * *}(120.75)$ & -12.051 & 0.0529 & 229.070* $(116.7)$ & -39.316 \\
\hline Singapore & $(0.001)$ & -0.135 & $(0.19)$ & & $1.303 *$ & \\
\hline Switzerland & -0.005 & 24.727 & $(2.63)$ & -0.003 & & \\
\hline United States & $0.669 * * *(0.17)$ & -0.277 & $65.428 * *$ & & $-13.174 * * *(4.27)$ & \\
\hline Bangladesh & -0.540 & 14.183 & -0.594 & & & \\
\hline Brazil & $-1.073 *$ & $112.359 * * *(31.5)$ & -12.382 & 0.769 & -50.730 & -60.103 \\
\hline China & $63.302 * * *(17.1)$ & 11.699 & $(186.5)$ & $(23.30)$ & -5.827 & $\mathbf{5 1 7 . 8 5 5 * * ( 2 0 7 . 2 )}$ \\
\hline Egypt & $\mathbf{0 . 1 8 3} * * \quad(0.07)$ & $13.071 * * * \quad(3.94)$ & -1.206 & $-0.271 * * \quad(0.10)$ & $-7.465 *$ & -0.386 \\
\hline India & $12.797 * * *(4.5)$ & $-12.91 * *$ & $72.571 * * * \quad(24.04)$ & $-22.010 * \quad(6.87)$ & & 21.538 \\
\hline Indonesia & $(0.67)$ & $(10.9)$ & $(21.22)$ & & & $(28.14)$ \\
\hline Iran & $(0.05)$ & $1.165 * *$ & -3.635 & & & \\
\hline Malaysia & -0.015 & $-6.505 * *$ & $6.553 * *$ & -0.086 & $(3.85)$ & $(3.68)$ \\
\hline Mexico & -0.125 & -9.197 & $(10.9)$ & -0.390 & 32.438** (12.23) & -17.000 \\
\hline Pakistan & $(0.81)$ & $-29.253 * * * \quad(9.3)$ & -0.111 & $-2.118^{*}$ & $21.47258 * *(8.71)$ & $\mathbf{- 9 . 2 9 3 * * *}(2.83)$ \\
\hline Philippines & -0.5489 & $-122.342 * * *(36.75)$ & 11.693 & $2.140 * * *(1.03)$ & $102.602 * * *(33.67)$ & $\mathbf{- 2 6 . 4 9 5} * * *(8.87)$ \\
\hline Russia & $(0.08)$ & $\mathbf{2 . 8 6 5 * * *}(0.57)$ & -10.329 & & & \\
\hline South Africa & $(0.07)$ & $(1.58)$ & -0.813 & $\mathbf{0 . 2 3 6} * * \quad(0.106)$ & & \\
\hline South Korea & $(0.04)$ & $(2.53)$ & $-13.512 * * *(3.10)$ & $\mathbf{0 . 2 1 1} * * *(0.061)$ & $-11.161 * *$ & $-3.862 * * * \quad(3.10)$ \\
\hline Turkey & $(0.17)$ & -11.018 & $-39.117 * * * \quad(9.80)$ & & $22.969 * *$ & -18.347 \\
\hline Vietnam & 0.963 & $(6.50)$ & $(4.36)$ & & & \\
\hline
\end{tabular}


Table 7 short-run and long-run dynamics for all countries

\begin{tabular}{|c|c|c|c|}
\hline \multirow{2}{*}{ Type of dynamic } & $\begin{array}{l}\text { Renewable energy } \\
\& \text { oil price }\end{array}$ & $\begin{array}{l}\text { Renewable energy } \\
\& \mathrm{CO}_{2} \text { emissions }\end{array}$ & $\begin{array}{l}\text { Renewable energy } \\
\text { \& GDP }\end{array}$ \\
\hline & \multicolumn{2}{|c|}{ Developed countries } & \\
\hline Short-run & $\begin{array}{l}\text { Australia, } \\
\text { Denmark }\end{array}$ & $\begin{array}{c}\text { Singapore, United } \\
\text { States }\end{array}$ & \\
\hline Long-run & $\begin{array}{c}\text { Canada, United } \\
\text { States }\end{array}$ & Germany & United States \\
\hline \multirow[t]{2}{*}{ Short and long-run } & - & $\begin{array}{l}\text { New Zealand, } \\
\text { Norway }\end{array}$ & - \\
\hline & \multicolumn{2}{|c|}{ Emerging countries } & \\
\hline Short-run & China & South Korea, Turkey & $\begin{array}{c}\text { South Africa, South } \\
\text { Korea }\end{array}$ \\
\hline Long run & $\begin{array}{c}\text { India, Malaysia, } \\
\text { Turkey }\end{array}$ & $\begin{array}{c}\text { Brazil, India, Iran, } \\
\text { Malaysia, Pakistan, } \\
\text { the Philippines, } \\
\text { Russia }\end{array}$ & Brazil, China, India \\
\hline Short and long-run & South Korea & - & - \\
\hline
\end{tabular}

\section{Short-run dynamics}

It is interesting to observe from the results (Table 6 and Table 7) that there was no statistically significant short-run relationship between RE and GDP for developed countries. However, the relationship between $\mathrm{RE}$ and $\mathrm{CO}_{2}$ was negative and statistically significant for developed countries. Similarly, the short-run relationship between RE and OP was positive and statistically significant for the developed countries. However, both these relationships (i.e., RE with $\mathrm{CO}_{2}$ and $\mathrm{RE}$ with OP) were statistically not significant for the emerging countries. The negative statistically significant result was consistent with the earlier findings for the same relationship in developed countries through FMOLS and DOLS. However, we also found a statistically significant and positive short-run relationship between $\mathrm{RE}$ and $\mathrm{OP}$ for developed countries indicating the substitution of RE for oil as the price of the latter increases.

The country-specific results for short-run dynamics showed a negative and statistically significant relationship between RE and GDP for India and Pakistan. In contrast, they showed a positive relationship for countries like South Korea, South Africa, and the Philippines. This indicates that, in the short-run, countries like India and Pakistan are struggling to increase their RE with GDP. However, countries like South Korea, South Africa, and the Philippines are doing well in terms of increasing RE as their GDP per capita rises. However, in most of the countries, the RE and GDP relationship was statistically not significant in the short run, indicating that their RE production is independent of their per capita GDP growth.

The $\mathrm{CO}_{2}$ positive relationship with RE for countries like New Zealand, Singapore, Norway, Mexico, Pakistan, Philippines, Turkey indicates that in these countries, $\mathrm{CO}_{2}$ and $\mathrm{RE}$ are going in the same direction. This may suggest that these countries are growing RE production, but at the same time, $\mathrm{CO}_{2}$ emissions (most probably due to energy from non-renewable energy sources) are also on the rise, thus causing both $\mathrm{RE}$ and $\mathrm{CO}_{2}$ to rise. On the other hand, for countries like Egypt, South Korea, and the USA, the relationship between RE and CO2 is negative and statistically significant, indicating that in these countries non-renewable energy production is increasing. 
Finally, the positive relationship between the RE and OP indicates that China is using renewable energy production as a substitute for oil in the short-run. In contrast, countries like Australia, Denmark, Pakistan, the Philippines, and South Korea are using it as an excellent complementary source of energy along with their traditional sources of power. This relationship was statistically not significant for other countries included in the sample.

\subsection{Causality Analysis}

We further applied the Granger test for causality between variables to seek the direction of causality between the renewable energy production variable (RE) and the other variables. The results of the Granger causality test are presented in Table A1 Annex A. The results are further elaborated using graphs in Figure 1, Figure 2, and Figure 3.

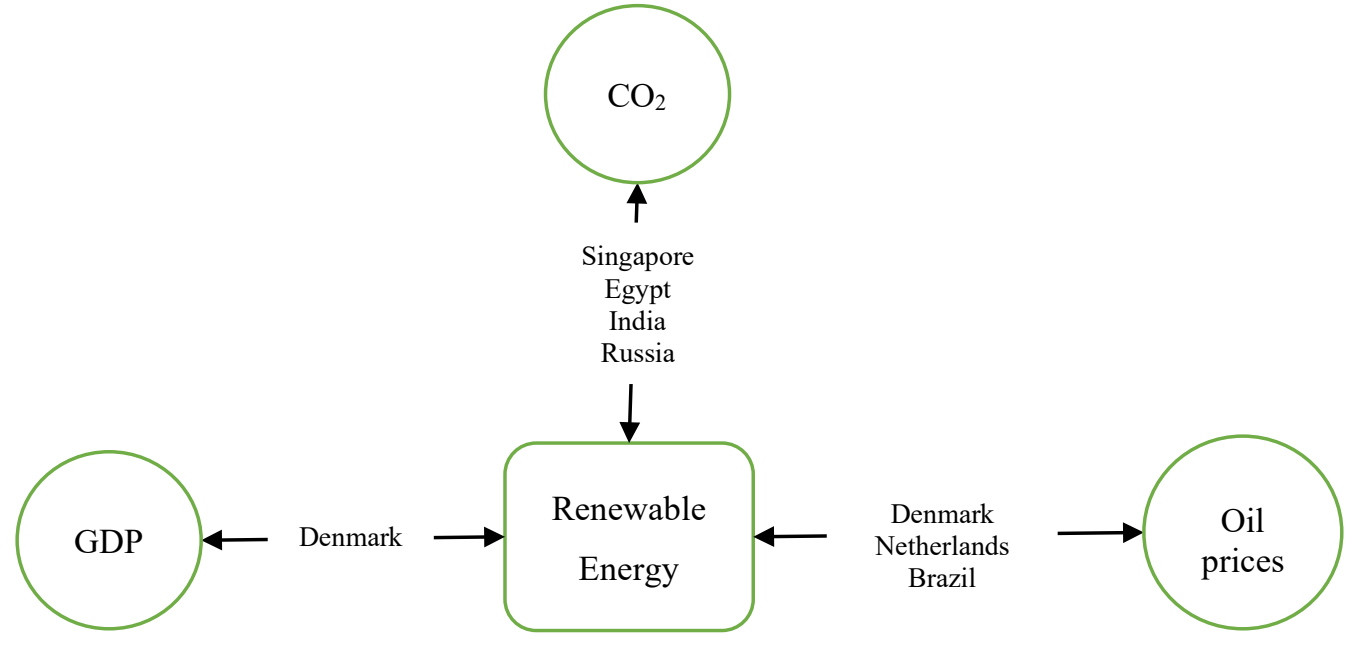

Figure 1 Bidirectional casualty between renewable energy \& all variables

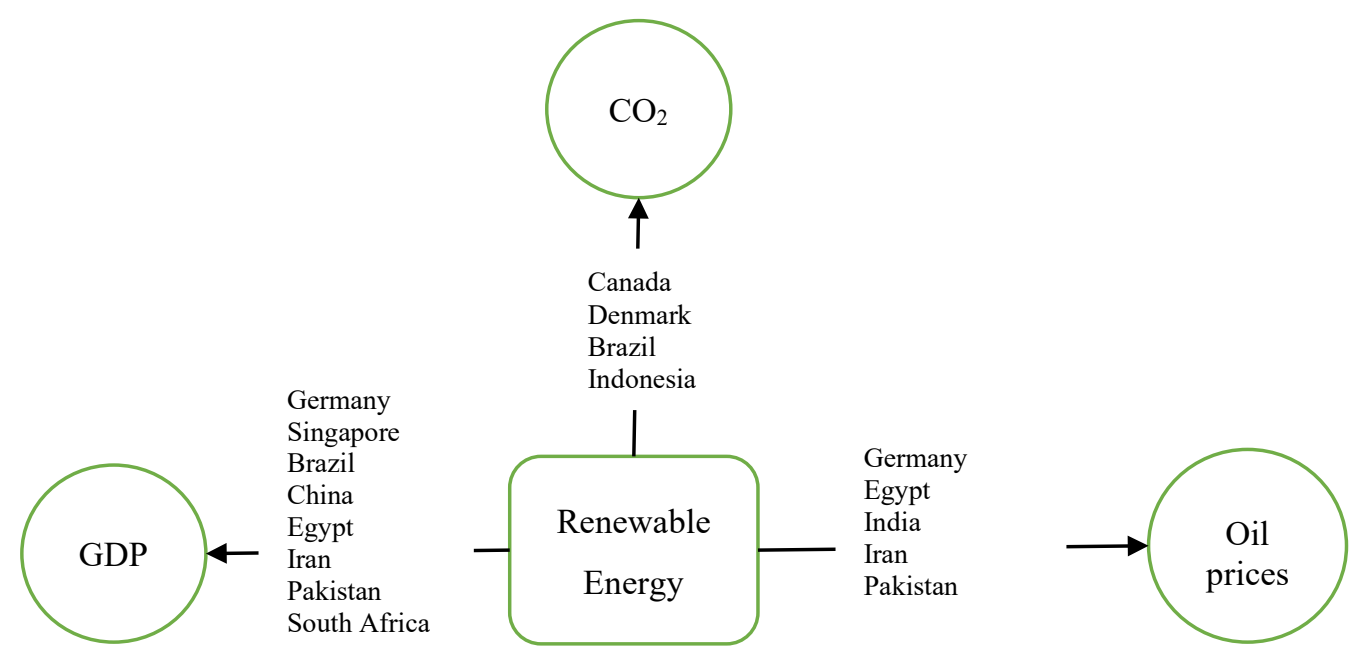

Figure 2 Unidirectional casualty 1 (Renewable Energy to GDP, $\mathrm{CO}_{2} \&$ Oil prices) 


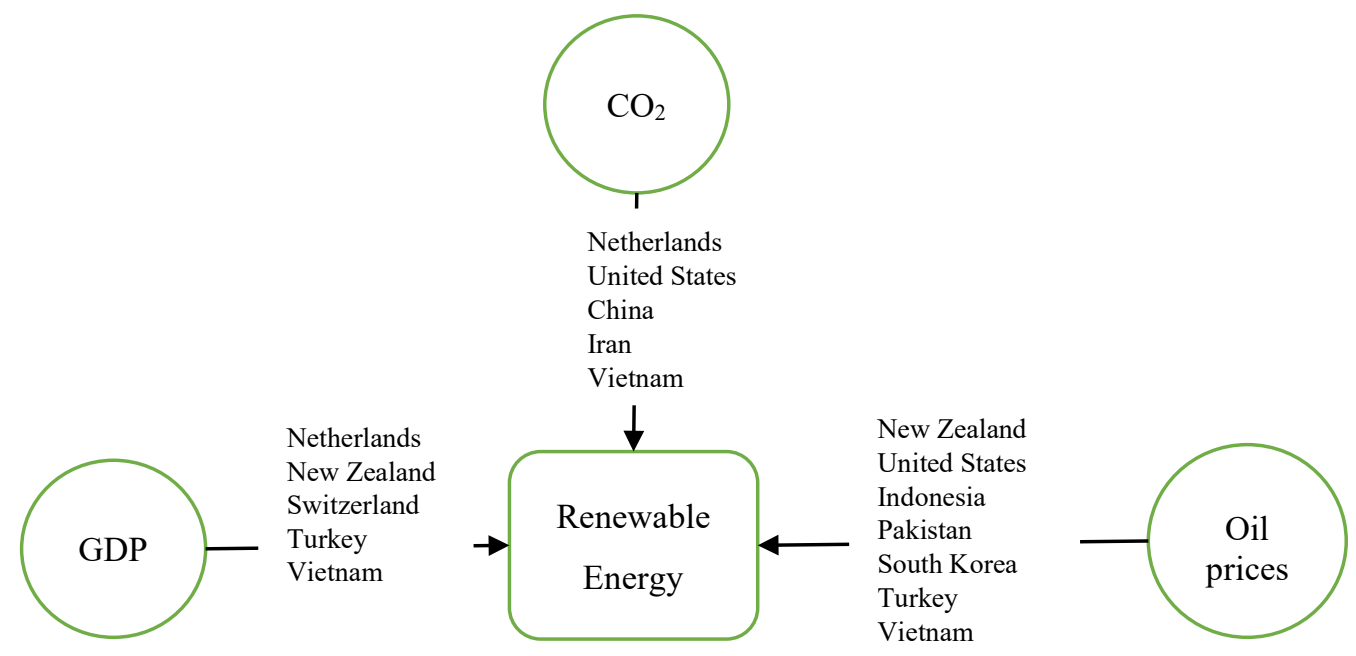

Figure 3 Unidirectional casualty (GDP, $\mathrm{CO}_{2}$ \& Oil prices to Renewable Energy)

The results from the Granger causality tests indicated bidirectional causality between $\mathrm{CO}_{2}$ and RE for Singapore, Egypt, India, and Russia, between RE and GDP for Denmark and between RE and OP for Denmark, Brazil, and the Netherlands. Similarly, we found a unidirectional causality from $\mathrm{RE}$ to $\mathrm{CO}_{2}$ for Canada, Denmark, Brazil, and Indonesia, from $\mathrm{RE}$ to GDP for Germany, Singapore, Brazil, China, Egypt, Iran, Pakistan, and South Africa and from RE to OP for Germany, Egypt, Iran, and Pakistan. Finally, we also found a unidirectional causality from $\mathrm{CO}_{2}$ to RE for the Netherlands, US, China, Iran, and Vietnam, from GDP to RE for the Netherlands, New Zealand, Switzerland, Turkey, and Vietnam and from OP to RE for New Zealand, US, Indonesia, Pakistan, South Korea, Turkey, and Vietnam.

These type of relationships between energy growth, renewable energy production, and $\mathrm{CO}_{2}$ is a well-studied area in scholarly literature. Furthermore, (Kula, 2014) reported a unidirectional causality between renewable energy and economic growth. In this case, investment in renewable energy schemes generates better energy access and jobs, thereby driving economic growth. In studies that find bidirectional relationships such as (Apergis \& Payne, 2012), there is a feedback loop. In essence, government policies ensure that a part of the economic growth resulting from renewable energy generation is invested back into renewables, thereby continuing the bidirectional causality loop. The variations in this relationship are largely dependent on policy decisions regarding investments in renewable technology (Bassi, 2009). Similarly, (Chen, Wang, \& Zhong, 2019) also reported a bidirectional causality between $\mathrm{RE}$ and $\mathrm{CO}_{2}$.

We may also refer to some studies of a similar kind at a specific country-level. For instance, (Rafiq, Bloch, \& Salim, 2014) reported unidirectional causality from $\mathrm{CO}_{2}$ emissions to RE and from RE to GDP and bidirectional long-run causality for India. However, they reported unidirectional shortrun causality from GDP to $\mathrm{RE}$ and from $\mathrm{CO}_{2}$ to $\mathrm{RE}$. But in the long-run it was unidirectional from GDP to RE and bidirectional between $\mathrm{CO}_{2}$ to RE. Similarly, (Salim, Rafiq, \& Hassan, 2008) reported bidirectional causality between energy consumption and income in Malaysia 


\section{CONCLUSION}

This research investigates the factors that determine renewable energy production in 10 developed and 16 emerging countries using data from 1976 till 2018. The study used three key variables, namely the per capita GDP, CO2 emissions, and oil prices and applied econometric models including regression analysis, autoregressive distributed lag models and Granger causality analysis.

The results of the analysis were exciting. We found a negative relationship between GDP per capita and renewable energy for emerging countries and a positive relationship for the developed countries. We concluded that developed countries are self-sufficient in meeting their overall energy demand, so when further increasing their energy output, they are concerned about emissions and renewable energy. On the other hand, many of the emerging countries are still unable to meet their energy needs, so they are meeting increasing energy demand with both increasing renewable and non-renewable energy. Thus, their emissions are also increasing. At the level of individual countries, we found that some countries are using oil as a substitute for renewable energy (mostly those countries that are developed and self-sufficient in energy production). In contrast, in other countries that are still struggling to meet their basic energy needs RE works as a complement to traditional energy sources. The results from short-run and long-run dynamics and causality analysis were unique to different countries. It is difficult to draw a general conclusion from these findings for specific country groups.

The world is more focused on renewable energy than ever before. The emerging economies included in our study are mostly developing countries that are net oil importers. On the other hand, some of the developed countries are also net oil importers but due to their higher per capita GDP they are less price-sensitive compared to emerging countries and are more focused on green energy through environmental taxes and emissions targets. Therefore, there is a rise in renewable energy production globally. Some other reasons behind this increase in renewable energy production can be internal (i.e., imposed by international environmental bodies) and external factors (i.e., motivated by a recognition of the consequences of environmental degradation on humankind). Therefore, in emerging countries, policymakers should focus on investing in the development of the renewable energy sector, which can enhance energy self-reliance and generate sustainable employment and growth. This goal can be attained with financial assistance from developed countries. Furthermore, $\mathrm{CO}_{2}$ emissions are on the rise in emerging countries and also in some developed countries despite increases in renewable energy production. These countries need to focus on moving more aggressively toward renewable energy production. For this purpose, policymakers in emerging economies can work on improving their legislation to set a conducive regulatory framework for modern, technology-based green energy production. The engagement of the private sector could be of great benefit as public-private partnership-based projects (especially in the infrastructure sector) have been phenomenal successes globally. The oil-exporting countries that are heavily reliant on oil revenue (such as Russia, Canada, and Norway) may focus on diversification for revenue sources (Wong \& El Massah, 2018) to avoid any oil price shocks. At the same time, Russia may consider moving toward more renewable energy production from their current energy mix that is heavily biased in favor of non-renewable energy sources (Mitrova \& Melnikov, 2019).

As these findings demonstrate, the determinants of conversion to renewable energy vary considerably from country to country. Consequently, different policy approaches are necessary to bring about the desired changes in different contexts. Further research is required to build upon 
and expand the scope of the present study, bringing in different countries to broaden our understanding of more of the world. This study can be extended to include more variables so that their impact on the increased production of renewable energy can also be evaluated relative to the factors analyzed in this study. Understanding and acting on appropriate renewable energy policies is more critical today than ever before. This is because of the tremendous global threats posed by runaway climate change and the opportunities that currently exist, which make this a particularly propitious time for countries to convert to renewable energy.

\section{References:}

Abanda, H. F., Ng'ombe, A., Keivani, R., \& Tah, J. H. (2012). The Link Between Renewable Energy Production and Gross Domestic Product in Africa: A Comparative Study Between 1980 and 2008. Renewable and Sustainable Energy Reviews, 16(4), 2147-2153.

Aguirre, M., \& Ibikunle, G. (2014). Determinants of Renewable Energy Growth: A Global Sample Analysis. Energy Policy, 69, 374-384.

Aguirre, M., \& Ibikunle, G. (2014). Determinants of Renewable Energy Growth: A Global Sample Analysis. Energy Policy, 69(C), 374-384.

Akar, B. (2016). The Determinants of Renewable Energy Consumption: An Empirical Analysis for the Balkans. European Journal of Scientific Research, 12(11), 594-607.

Ali, S., Anwar, S., \& Samina, N. (2017). Renewable and Non-Renewable Energy and its Impact on Environmental Quality in South Asian Countries. Forman Journal of Economic Studies, 13, 177-194.

Al-Mulali, U., Fereidouni, H. G., Lee, J. Y., \& Sab, C. N. (2013). Examining the Bi-directional Long-Run Relationship Between Renewable Energy Consumption and GDP growth. Renewable and Sustainable Energy Reviews, 22, 209-222.

Apergis, N., \& Payne, J. E. (2010). Renewable Energy Consumption and Growth in EURASIA. Energy Economics, 32(6), 1392-1397.

Apergis, N., \& Payne, J. E. (2011). Renewable and Non-Renewable Electricity Consumption Growth Nexus: Evidence from Emerging Market Economies. Applied Energy, 88(12), 5226-5230.

Apergis, N., \& Payne, J. E. (2012). Renewable and Non-renewable Energy Consumption-Growth Nexus: Evidence from a Panel Error Correction Model. Energy Economics, 34, 733-738.

Augutis, J., Martišauskas, L., Krikštolaitis, R., \& Augutienè, E. (2014). Impact of the Renewable Energy Sources on the Energy Security. Energy Procedia, 61, 945-948.

Bassi, A. M. (2009). An Integrated Approach to Support Energy Policy Formulation and Evaluation, PhD Thesis. University of Bergen: Norway.

Bento, J. P., \& Moutinho, V. (2016). CO2 Emissions, Nonrenewable and Renewable Electricity Production, Economic Growth, and International Trade in Italy. Renewable and Sustainable Energy Reviews, 55, 142-155.

Bhattacharya, M., Paramati, S. R., Ozturk, I., \& Bhattacharya, S. (2016). The Effect of Renewable Energy Consumption on Economic Growth: Evidence from Top 38 Countries. Applied Energy, 162, 733-741.

Bird, L., Bolinger, M., Gagliano, T., Wiser, R., Brown, M., \& Parsons, B. (2005). Policies and Market Factors Driving Wind Power Development in the United States. Energy Policy, 33(11), 1397-1407. 
BP. (2019). Statistical Review of World Energy 2019. Retrieved November 9, 2020, from British Petroleum: http://www.bp.com/en/global/corporate/energy-economics/statistical-reviewof-world-energy.html

Carley, S. (2009). State Renewable Energy Electricity Policies: An Empirical Evaluation of Effectiveness. Energy Policy, 37(8), 3071-3081.

Chang, T.-H., Huang, C.-M., \& Lee, M.-C. (2009). Threshold Effect of the Economic Growth Rate on the Renewable Energy Development from a Change in Energy Price: Evidence from OECD Countries. Energy Policy, 31(12), 5796-5802.

Chassot, S., Hampl, N., \& Wüstenhagen, R. (2014). When Energy Policy Meets Free-Market Capitalists: The Moderating Influence of Worldviews on Risk Perception and Renewable Energy Investment Decisions. Energy Research \& Social Science, 3, 143-151.

Chen, Y., Wang, Z., \& Zhong, Z. (2019). CO2 Emissions, Economic Growth, Renewable and Non-renewable Energy Production and Foreign Trade in China. Renewable Energy, 131, 208-216.

Chien, T., \& Hub, J.-L. (2008). Renewable Energy: An Efficient Mechanism to Improve GDP. Energy Policy, 36(8), 3045-3052.

Cho, C.-H., Yang, L.-J., Chu, Y.-P., \& Yang, H.-Y. (2013). Renewable Energy and Renewable R\&D in EU Countries: A Cointegration Analysis. Asian Journal of Natural \& Applied Sciences, 2(1), 1-11.

Choi, I. (2006). Nonstationary Panels. In H. Hassani, M. Terence C, \& K. Patterson, Palgrave Handbook of Econometrics Volume 1: Econometric Theory. Palgrave Macmillan: London, UK.

Cornish, D. B., \& Clarke, R. V. (1987). Understanding Crime Displacement: An Application of Rational Choice Theory. Criminology, 25(4), 933-948.

Da Silva, P. P., Cerqueira, P. A., \& Ogbe, W. (2018). Determinants of Renewable Energy Growth in Sub-Saharan Africa: Evidence from Panel ARDL. Energy, 156, 45-54.

Den Elzen, M. G., Olivier, J. G., Höhne, N., \& Janssens-Maenhout, G. (2013). Countries' Contributions to Climate Change: Effect of Accounting for all Greenhouse Gases, Recent Trends, Basic Needs and Technological Progress. Climatic Change, 121(2), 397-412.

Dogan, E., \& Seker, F. (2016). Determinants of CO2 Emissions in the European Union: The Role of Renewable and Nonrenewable Energy. Renewable Energy, 94, 429-439.

Dvořák, P., Martinát, S., Vander Horst, D., Frantál, B., \& Turečková, K. (2017). Renewable Energy Investment and Job Creation; A Cross-Sectoral Assessment for the Czech Republic with Reference to EU Benchmarks. Renewable and Sustainable Energy Reviews, 69, 360-368.

Farahani, H. A., Rahiminezhad, A., \& Same, L. (2010). A Comparison of Partial Least Squares (PLS) and Ordinary Least Squares (OLS) Regressions in Predicting of Couples Mental Health Based on their Communicational Patterns. Procedia-Social and Behavioral Sciences, 5, 1459-1463.

Francés, G. E., Marín-Quemada, J. M., \& Gonzáleza, E. S. (2013). RES and Risk: Renewable Energy's Contribution to Energy Security. A Portfolio-Based Approach. Renewable and Sustainable Energy Reviews,, 26, 549-559.

Gan, L., Eskeland, G. S., \& Kolshus, H. H. (2007). Green Electricity Market Development: Lessons from Europe and the US. Energy Policy, 35(1), 144-155.

Greene, W. H. (2003). Econometric Analysis. Prentice Hall Publishers: New Jersey, USA. 
Gujarati, D. N. (2011). Econometrics by Example (2nd ed.). New York, United States: Macmillan Publishers.

Guy, D. B. (2008). Empirical Analysis and Forecast of Electricity Demand in West African Economic and Monetary Zone: Evidence from Panel ADRL Modelling. Asian Journal of Economic Modelling, 6(3), 257-273.

Halder, S., Dirmeyer, A. P., \& Saha, S. K. (2015). Sensitivity of the Mean and Variability of Indian Summer Monsoon to Land Surface Schemes in RegCM4: Understanding Coupled Land-Atmosphere Feedbacks. Journal of Geophysical Research Atmospheres, 120(18), 9437-9458.

Haseeb, M., Abidin, I. S., Hye, Q. M., \& Hartani, N. H. (2019). The Impact of Renewable Energy on Economic Well-being of Malaysia: Fresh Evidence From Auto Regressive Distributed Lag Bound Testing Approach. International Journal of Energy Economics and Policy, 9(1).

Hillebrand, B., Buttermann, H. G., Behringer, J. M., \& Bleuel, M. (2006). The Expansion of Renewable Energies and Employment Effects in Germany. Energy Policy, 34(18), 34843494.

Huntington, H. G. (2009). The Oil Security Problem. In J. Evans, \& C. L. Hunt, International Handbook on the Economics of Energy. Chapter 16, Edward Elgar Publishing.

IEA. (2012). Renewables Information 2012. International Energy Agency: OECD Publishing, Paris, https://doi.org/10.1787/renew-2012-en.

IEA. (2019a). Key World Energy Statistics 2019. International Energy Agency (IEA): Paris, France. Retrieved November 8, 2020, from https:/webstore.iea.org/key-world-energystatistics-2019

Igliński, B., Iglińska, A., Cichosz, M., Kujawski, W., \& Buczkowski, R. (2016). Renewable Energy Production in the Lódzkie Voivodeship. The PEST Analysis of the RES in the Voivodeship and in Poland. Renewable and Sustainable Energy Reviews, 58(C), 737-750.

IRENA. (2019). Renewable Power Generation Costs in 2018. International Renewable Energy Agency: Abu Dhabi, UAE.

Kahia, M., Aissa, B., \& Safouane, M. (2014). Renewable and non-renewable energy consumption and economic growth: Evidence from MENA Net Oil Exporting Countries. Paper No. 80776. MPRA Paper 80776 : University Library of Munich, Germany.

Kurths, A. W., \& Pikovsky, A. (1998). Testing Stationarity in Time Series. Physical Review E, $58(2), 1800$.

Leybourne, S. J., McCabe, B. P., \& Tremayne, A. R. (1996). Can Economic Time Series be Differencing to Stationarity? Journal of Business \& Economic Statistics, 14(4), 435-446.

Mankiw, N. G. (2019). Principles of Microeconomics, 9e. Cengage Learning: USA.

Marques, A. C., \& Fuinhas, J. A. (2012). Are Public Policies Towards Renewables Successful? Evidence from European Countries. Renewable Energy, 44, 109-118.

Marques, A. C., Fuinhas, J. A., \& Manso, J. R. (2010). Motivations Driving Renewable Energy in European Countries: A Panel Data Approach. Energy Policy, 38(11), 6877-6885.

Mitrova, T., \& Melnikov, Y. (2019). Energy transition in Russia. Energy Transitions, 3, 73-80.

Mohiuddin, O., Asumadu-Sarkodie, S., \& Obaidullah, M. (2016). The Relationship Between Carbon Dioxide Emissions, Energy Consumption, and GDP: A Recent Evidence from Pakistan. Cogent Engineering , 3(1), 1-16.

Moran, R. (1996). Bringing Rational Choice Theory Back to Reality. Journal of Criminal Law \& Criminology, 86(3), 1147-1160. 
Nesta, L., Vona, F., \& Nicolli, F. (2014). Environmental Policies, Competition and Innovation in Renewable Energy. Journal of Environmental Economics and Management, 67(3), 396411.

OECD. (2019). Renewable energy. Retrieved November 9, 2020, from The Organisation for Economic Co-operation and Development: https://data.oecd.org/energy/renewableenergy.htm

Ohler, A., \& Fetters, I. (2014). The Causal Relationship Between Renewable Electricity Generation and GDP Growth: A Study of Energy Sources. Energy Economics, 43, 125139.

Omri, A., \& Nguyen, D. K. (2014). On the Determinants of Renewable Energy Consumption: International Evidence. Energy, 72, 554-560.

Pedroni, P. (2001). Nonstationary Panels, Panel Cointegration, and Dynamic Panels. Fully Modified OLS for Heterogeneous Cointegrated Panels. In B. H. Baltagi, T. .. Fomby, \& R. Carter Hill, Advances in Econometrics, Vol. 15 (pp. 93-130). Emerald Group Publishing : Bingley, UK.

Pesaran, M. H., Shin, Y., \& Smith, R. J. (2001). Bounds testing approaches to the analysis of level relationships. Journal of Applied Econometrics, 16(3), 289-326.

Polzin, F., Migendt, M., Täubec, F. A., \& von Flotow, P. (2015). Public Policy Influence on Renewable Energy Investments-A Panel Data Study Across OECD Countries. Energy Policy, 80, 98-111.

Popp, D., Hascic, I., \& Medhi, N. (2011). Technology and the Diffusion of Renewable Energy. Energy Economics, 33(4), 648-662.

Przychodzen, W., \& Przychodzen, J. (2020). Determinants of Renewable Energy Production in Transition Economies: A Panel Data Approach. Energy, 191, 1-28.

Rafiq, S., Bloch, H., \& Salim, R. (2014). Determinants of Renewable Energy Adoption in China and India: A Comparative Analysis. Applied Economics, 46(22), 2700-2710.

Reboredo, J. C. (2015). Is There Dependence and Systemic Risk Between Oil and Renewable Energy Stock Prices . Energy Economics, 48, 32-45.

REN21. (2019). Renewables, 2019; Global Status Report. Renewables Now! (REN21): Paris, France. Retrieved November 8, 2020, from https://www.ren21.net/wpcontent/uploads/2019/05/gsr_2019_full_report_en.pdf

Sadorsky, P. (2009). Renewable Energy Consumption, CO2 Emissions and Oil Prices in the G7 Countries. Energy Economics, 31(3), 456-462.

Salim, R. A., Rafiq, S., \& Hassan, A. F. (2008). Causality And Dynamics Of Energy Consumption And Output: Evidence From Non-Oecd Asian Countries. Journal of Economic Development, 33(2), 1-26.

Seetharaman, Moorthy, K., Patwa, N., Saravanan, \& Gupta, Y. (2019). Breaking Barriers in Deployment of Renewable Energy. Heliyon, 5(1), e01166.

Shahbaz, M., \& Lean, H. H. (2012). Does Financial Development Increase Energy Consumption? The Role of Industrialization and Urbanization in Tunisia. Energy Policy, 40, 473-479.

Shahbaz, M., Adnan, Q. M., Tiwari, A. K., \& Leitão, N. C. (2013). Economic Growth, Energy Consumption, Financial Development, International Trade and $\mathrm{CO} 2$ Emissions in Indonesia. Renewable and Sustainable Energy Reviews, 25, 109-121.

Shrestha, M. B., \& Bhatta, G. R. (2018). Selecting Appropriate Methodological Framework for Time Series Data Analysis. The Journal of Finance and Data Science, 4(2), 71-89. 
Shukla, A. K., Sudhakar, K., \& Baredar, P. (2017). Renewable Energy Resources in South Asian Countries: Challenges, Policy and Recommendations. Resource-Efficient Technologies, 3(3), 342-346.

Siddiqui, A. S., Tanaka, M., \& Chen, Y. (2016). Are Targets for Renewable Portfolio Standards Too Low? The Impact of Market Structure on Energy Policy. European Journal of Operational Research, 250(1), 328-341.

Smith, R. P. (2000). Estimation and Inference with Non-stationary Panel Time-series Data. Working Paper, Department of Economics: Birkbeck College, London.

Soytas, U., \& Sari, R. (2003). Energy Consumption and GDP: Causality Relationship in G-7 Countries and Emerging Markets. Energy economics, 25(1), 33-37.

Stadelmann, M., \& Castro, P. (2014). Climate Policy Innovation in the South - Domestic and International Determinants of Renewable Energy Policies in Developing and Emerging Countries. Global Environmental Change, 29, 413-423.

Sunde, T. (2017). Foreign Direct Investment, Exports and Economic Growth: ADRL and Causality Analysis for South Africa. Research in International Business and Finance, 41, 434-444.

Tariq, G., Sun, H., Haris, M., Javaid, H. M., \& Kong, Y. (2018). Energy Consumption and Economic Growth: Evidence from Four Developing Countries. American Journal of Multidisciplinary Research, 7(1), 2356-6191.

The Economist. (2020). The World's Energy System Must be Transformed Completely. Retrieved November 6, 2020, from The Economist website: https:/www.economist.com/schoolsbrief/2020/05/23/the-worlds-energy-system-must-be-transformed-completely

UN. (2019). National Accounts - Analysis of Main Aggregates (AMA). Retrieved November 9, 2020, from United Nations: https://unstats.un.org/unsd/snaama/Index

Wei, T., Yang, S., Moore, C. J., Shi, P., Cuia, X., \& et al. (2012). Developed and Developing World Responsibilities for Historical Cimate Change and CO2 Mitigation. Proceedings of the National Academy of Sciences, 109(32), 12911-12915.

Wong, V. S., \& El Massah, S. (2018). Recent Evidence on the Oil Price Shocks on Gulf Corporation Council Stock Markets. International Journal of the Economics of Business, 25(2), 297-312 .

World Economic Forum. (2020). These countries are leading the transition to sustainable energy. Retrieved November 6, 2020, from World Economic Forum website: https://www.weforum.org/agenda/2020/05/energy-transition-index-2020-eti-cleansustainable-power/

Xu, X., Wei, Z., Ji, Q., Wang, C., \& Gao, G. (2019). Global Renewable Energy Development: Influencing Factors, Trend Predictions and Countermeasures. Resources Policy, 63, 101470.

Yazdi, S. K., \& Shakouri, B. (2017). Renewable Energy, Nonrenewable Energy Consumption, and Economic Growth. Energy Sources, Part B: Economics, Planning, and Policy, 12(12), 1038-1045.

Zhang, X.-P., \& Cheng, X.-M. (2009). Energy Consumption, Carbon Emissions, and Economic Growth in China. Ecological Economics, 68(10), 2706-2712.

Zhao, Z.-Y., Chen, Y.-L., \& Li, H. (2019). What Affects the Development of Renewable Energy Power Generation Projects in China: ISM Analysis. Renewable Energy, 131, 506-517. 


\section{Appendix A}

Table A.1 Results of the Granger causality test

\begin{tabular}{|c|c|c|c|c|c|}
\hline & & $\triangle \mathrm{RE}$ & $\Delta \mathrm{GDP}$ & $\Delta \mathrm{CO}_{2}$ & $\Delta \mathrm{OP}$ \\
\hline \multirow{4}{*}{ All Countries } & $\Delta \mathrm{RE}$ & & 0.41 & $25.04 * * *$ & 1.30 \\
\hline & $\Delta \mathrm{GDP}$ & 0.17 & & $4.00 * *$ & $14.34 * *$ \\
\hline & $\Delta \mathrm{CO}_{2}$ & $4.33 * *$ & 0.15 & & 1.63 \\
\hline & $\Delta \mathrm{OP}$ & 0.15 & $23.12 * * *$ & 3.04** & \\
\hline \multirow{4}{*}{$\begin{array}{c}\text { Developed } \\
\text { Countries }\end{array}$} & $\Delta \mathrm{RE}$ & & 0.0002 & 0.90 & 1.30 \\
\hline & $\Delta \mathrm{GDP}$ & 0.26 & & 0.54 & $18.21 * * *$ \\
\hline & $\Delta \mathrm{CO}_{2}$ & $26.59 * * *$ & 0.03 & & 0.026 \\
\hline & $\Delta \mathrm{OP}$ & 2.18 & $14.63 * * *$ & $4.75 * * *$ & \\
\hline \multirow{4}{*}{$\begin{array}{l}\text { Emerging } \\
\text { Countries }\end{array}$} & $\Delta \mathrm{RE}$ & & 1.82 & $9.45 * * *$ & 0.74 \\
\hline & $\Delta \mathrm{GDP}$ & 0.27 & & $3.61 * *$ & $11.94 * * *$ \\
\hline & $\Delta \mathrm{CO}_{2}$ & $20.37 * * *$ & 0.87 & & $2.42 *$ \\
\hline & $\Delta \mathrm{OP}$ & 0.68 & $10.86 * * *$ & 1.51 & \\
\hline \multicolumn{6}{|c|}{ Developed Countries } \\
\hline \multirow{4}{*}{ Australia } & $\Delta \mathrm{RE}$ & & $2.54 *$ & 0.09 & 0.60 \\
\hline & $\Delta \mathrm{GDP}$ & 0.94 & & 1.50 & $15.67 * * *$ \\
\hline & $\Delta \mathrm{CO}_{2}$ & 0.48 & $3.27 * *$ & & $3.20 *$ \\
\hline & $\Delta \mathrm{OP}$ & 1.93 & $10.11 * * *$ & $2.49 *$ & \\
\hline \multirow{4}{*}{ Canada } & $\Delta \mathrm{RE}$ & & 0.78 & 2.93* & 0.34 \\
\hline & $\Delta \mathrm{GDP}$ & 1.82 & & 0.32 & $11.66 * * *$ \\
\hline & $\Delta \mathrm{CO}_{2}$ & 0.002 & $2.78 *$ & & 2.18 \\
\hline & $\Delta \mathrm{OP}$ & 0.73 & $12.24 * * *$ & $5.34 * * *$ & \\
\hline \multirow{4}{*}{ Denmark } & $\Delta \mathrm{RE}$ & & 2.91* & $3.93 * *$ & $4.58 * *$ \\
\hline & $\Delta \mathrm{GDP}$ & $3.66 * *$ & & 2.16 & 1.90 \\
\hline & $\Delta \mathrm{CO}_{2}$ & 0.66 & 1.12 & & 0.35 \\
\hline & $\Delta \mathrm{OP}$ & $6.63 * * *$ & 1.60 & 2.26 & \\
\hline \multirow{4}{*}{ Germany } & $\Delta \mathrm{RE}$ & & $4.19 * *$ & 0.79 & $6.84 * * *$ \\
\hline & $\Delta \mathrm{GDP}$ & 2.00 & & $5.20 * *$ & 1.16 \\
\hline & $\Delta \mathrm{CO}_{2}$ & 2.38 & 2.20 & & 1.51 \\
\hline & $\Delta \mathrm{OP}$ & 0.40 & 0.41 & 2.40 & \\
\hline \multirow{4}{*}{ Netherlands } & $\Delta \mathrm{RE}$ & & 0.93 & 1.96 & $2.75 *$ \\
\hline & $\Delta \mathrm{GDP}$ & $9.84 * * *$ & & 0.05 & $2.55 *$ \\
\hline & $\Delta \mathrm{CO}_{2}$ & 3.12* & $3.66 * *$ & & 2.96* \\
\hline & $\Delta \mathrm{OP}$ & $3.39 * *$ & 2.19 & $4.10 * *$ & \\
\hline \multirow{4}{*}{ New Zealand } & $\Delta \mathrm{RE}$ & & 2.40 & 0.13 & 0.76 \\
\hline & $\Delta \mathrm{GDP}$ & $4.21 * *$ & & 1.08 & $5.73 * * *$ \\
\hline & $\Delta \mathrm{CO}_{2}$ & 0.46 & $4.11 * *$ & & $4.45^{* *}$ \\
\hline & $\Delta \mathrm{OP}$ & $4.43 * *$ & 2.24 & 1.47 & \\
\hline \multirow{4}{*}{ Norway } & $\Delta \mathrm{RE}$ & & 0.83 & 0.87 & 0.20 \\
\hline & $\Delta \mathrm{GDP}$ & 1.64 & & 0.40 & $4.87 * *$ \\
\hline & $\Delta \mathrm{CO}_{2}$ & 1.57 & 1.62 & & 1.92 \\
\hline & $\Delta \mathrm{OP}$ & 0.33 & $6.03 * * *$ & 0.13 & \\
\hline \multirow{4}{*}{ Singapore } & $\Delta \mathrm{RE}$ & & $2.78 *$ & $2.64 *$ & 1.16 \\
\hline & $\Delta \mathrm{GDP}$ & 1.67 & & 0.08 & $5.67 * * *$ \\
\hline & $\Delta \mathrm{CO}_{2}$ & $5.26 * * *$ & $10.66 * * *$ & & 2.07 \\
\hline & $\Delta \mathrm{OP}$ & 0.26 & $4.74 * *$ & 0.25 & \\
\hline
\end{tabular}




\begin{tabular}{|c|c|c|c|c|c|}
\hline \multirow{4}{*}{ Switzerland } & $\Delta \mathrm{RE}$ & & 0.67 & 1.75 & 0.47 \\
\hline & $\Delta \mathrm{GDP}$ & $6.49 * * *$ & & 0.94 & 1.00 \\
\hline & $\Delta \mathrm{CO}_{2}$ & 0.12 & 1.02 & & 0.36 \\
\hline & $\Delta \mathrm{OP}$ & 1.82 & 0.04 & 2.17 & \\
\hline \multirow{4}{*}{ United States } & $\Delta \mathrm{RE}$ & & 0.95 & 0.16 & 0.62 \\
\hline & $\Delta \mathrm{GDP}$ & 1.71 & & 0.61 & 1.57 \\
\hline & $\Delta \mathrm{CO}_{2}$ & 3.13* & 1.20 & & 0.99 \\
\hline & $\Delta \mathrm{OP}$ & $2.57 *$ & $4.99 * *$ & 2.27 & \\
\hline \multicolumn{6}{|c|}{ Emerging Countries } \\
\hline \multirow{4}{*}{ Bangladesh } & $\Delta \mathrm{RE}$ & & 0.05115 & 0.37 & 1.51 \\
\hline & $\Delta \mathrm{GDP}$ & 0.20 & & 0.36 & 0.55 \\
\hline & $\Delta \mathrm{CO}_{2}$ & 0.17 & 1.10 & & 1.66 \\
\hline & $\Delta \mathrm{OP}$ & 0.33 & $5.42 * * *$ & 0.50 & \\
\hline \multirow{4}{*}{ Brazil } & $\Delta \mathrm{RE}$ & & $4.66 * *$ & $2.70 *$ & $2.59 *$ \\
\hline & $\Delta \mathrm{GDP}$ & 0.83 & & $4.01 * *$ & $2.56 *$ \\
\hline & $\Delta \mathrm{CO}_{2}$ & 2.40 & 2.49* & & 0.70 \\
\hline & $\Delta \mathrm{OP}$ & $3.66 * *$ & $4.25 * *$ & 0.99 & \\
\hline \multirow{4}{*}{ China } & $\Delta \mathrm{RE}$ & & $17.20 * * *$ & 0.26 & 0.30 \\
\hline & $\Delta \mathrm{GDP}$ & 2.40 & & $2.50 *$ & 0.80 \\
\hline & $\Delta \mathrm{CO}_{2}$ & $6.90 * * *$ & $5.52 * * *$ & & $10.40 * *$ \\
\hline & $\Delta \mathrm{OP}$ & 1.20 & $3.44 * *$ & 0.80 & \\
\hline \multirow{4}{*}{ Egypt } & $\Delta \mathrm{RE}$ & & $2.55 *$ & $4.24 * *$ & 1.70 \\
\hline & $\Delta \mathrm{GDP}$ & 2.15 & & 1.15 & 1.01 \\
\hline & $\Delta \mathrm{CO}_{2}$ & 3.01* & $5.85 * * *$ & & $2.84 *$ \\
\hline & $\triangle \mathrm{OP}$ & 0.48 & $9.10 * * *$ & 0.56 & \\
\hline \multirow{4}{*}{ India } & $\Delta \mathrm{RE}$ & & 1.68 & $19.97 * * *$ & $4.15 * *$ \\
\hline & $\Delta \mathrm{GDP}$ & 1.32 & & 2.20 & $7.48 * * *$ \\
\hline & $\Delta \mathrm{CO}_{2}$ & $5.53 * * *$ & 2.22 & & 1.15 \\
\hline & $\Delta \mathrm{OP}$ & 1.91 & $4.01 \% *$ & $12.08 * * *$ & \\
\hline \multirow{4}{*}{ Indonesia } & $\Delta \mathrm{RE}$ & & 2.21 & $4.73 * *$ & 1.98 \\
\hline & $\Delta \mathrm{GDP}$ & 2.13 & & 1.87 & $3.83 * *$ \\
\hline & $\Delta \mathrm{CO}_{2}$ & 0.40 & 2.90* & & 1.00 \\
\hline & $\Delta \mathrm{OP}$ & $2.46 *$ & 3.15* & $6.25 * * *$ & \\
\hline \multirow{4}{*}{ Iran } & $\Delta \mathrm{RE}$ & & $2.76^{*}$ & 0.40 & $7.21 * * *$ \\
\hline & $\Delta \mathrm{GDP}$ & 1.42 & & 2.17 & $7.20 * * *$ \\
\hline & $\Delta \mathrm{CO}_{2}$ & $4.66 * *$ & $3.35 * *$ & & 1.93 \\
\hline & $\Delta \mathrm{OP}$ & 1.11 & $3.55 * *$ & $6.45^{* * * *}$ & \\
\hline \multirow{4}{*}{ Malaysia } & $\Delta \mathrm{RE}$ & & 0.08 & 1.07 & 0.06 \\
\hline & $\Delta \mathrm{GDP}$ & 0.57 & & 1.24 & 1.13 \\
\hline & $\Delta \mathrm{CO}_{2}$ & 0.70 & $4.05 * *$ & & 2.01 \\
\hline & $\Delta \mathrm{OP}$ & 0.03 & 1.33 & 0.68 & \\
\hline \multirow{4}{*}{ Mexico } & $\Delta \mathrm{RE}$ & & 1.61 & 0.42 & 0.25 \\
\hline & $\Delta \mathrm{GDP}$ & 1.41 & & 1.70 & 1.47 \\
\hline & $\Delta \mathrm{CO}_{2}$ & 0.20 & $5.24 * * *$ & & 2.13 \\
\hline & $\Delta \mathrm{OP}$ & $2.90 *$ & 0.69 & 1.62 & \\
\hline
\end{tabular}




\begin{tabular}{|c|c|c|c|c|c|}
\hline \multirow{4}{*}{ Pakistan } & $\Delta \mathrm{RE}$ & & $7.59 * * *$ & $16.51 * * *$ & 1.78 \\
\hline & $\Delta \mathrm{GDP}$ & 1.88 & & 0.33 & 1.55 \\
\hline & $\Delta \mathrm{CO}_{2}$ & 0.91 & $7.85 * * *$ & & 2.25 \\
\hline & $\Delta \mathrm{OP}$ & $3.22 *$ & $3.38 * *$ & $2.89 *$ & \\
\hline \multirow{4}{*}{ Philippines } & $\Delta \mathrm{RE}$ & & 1.64 & 0.27 & 0.62 \\
\hline & $\Delta \mathrm{GDP}$ & 2.17 & & $4.06^{* * *}$ & 1.24 \\
\hline & $\Delta \mathrm{CO}_{2}$ & 2.10 & 1.03 & & 1.32 \\
\hline & $\Delta \mathrm{OP}$ & 0.26 & 1.74 & $5.22 * *$ & \\
\hline \multirow{4}{*}{ Russia } & $\Delta \mathrm{RE}$ & & 0.52 & $9.53 * * *$ & 1.10 \\
\hline & $\Delta \mathrm{GDP}$ & 0.11 & & $2.65 \%$ & $5.28 * * *$ \\
\hline & $\Delta \mathrm{CO}_{2}$ & $12.10 * * *$ & 0.54 & & 1.21 \\
\hline & $\Delta \mathrm{OP}$ & 0.18 & $4.85 \% *$ & $4.93 * *$ & \\
\hline \multirow{4}{*}{ South Africa } & $\Delta \mathrm{RE}$ & & $3.40 * *$ & 0.45 & 1.55 \\
\hline & $\Delta \mathrm{GDP}$ & 0.42 & & 1.32 & $9.89 * * *$ \\
\hline & $\Delta \mathrm{CO}_{2}$ & 0.71 & $3.59 * *$ & & 1.58 \\
\hline & $\Delta \mathrm{OP}$ & 0.13 & 1.20 & 0.62 & \\
\hline \multirow{4}{*}{ South Korea } & $\Delta \mathrm{RE}$ & & 0.73 & 0.36 & 0.93 \\
\hline & $\Delta \mathrm{GDP}$ & 0.74 & & 0.37 & $3.38 * *$ \\
\hline & $\Delta \mathrm{CO}_{2}$ & 1.76 & $5.72 * * *$ & & 1.50 \\
\hline & $\Delta \mathrm{OP}$ & 3.08* & $3.04 *$ & 1.41 & \\
\hline \multirow{4}{*}{ Turkey } & $\Delta \mathrm{RE}$ & & 2.32 & 1.19 & 1.16 \\
\hline & $\Delta \mathrm{GDP}$ & $5.46 * * *$ & & 0.67 & $3.40 * *$ \\
\hline & $\Delta \mathrm{CO}_{2}$ & 2.18 & 0.91 & & 1.84 \\
\hline & $\Delta \mathrm{OP}$ & $9.78 * * *$ & $4.03 * *$ & 0.44 & \\
\hline \multirow{4}{*}{ Vietnam } & $\Delta \mathrm{RE}$ & & 1.93 & 1.22 & 0.97 \\
\hline & $\Delta \mathrm{GDP}$ & $2.76 *$ & & 3.13* & 0.74 \\
\hline & $\Delta \mathrm{CO}_{2}$ & $4.53 * *$ & $4.05 * *$ & & $4.52 * *$ \\
\hline & $\Delta \mathrm{OP}$ & $4.80 * *$ & 0.12 & 2.01 & \\
\hline
\end{tabular}

$*, * *$, and $* * * *$ indicate significant at 10\%, 5\%, and $1 \%$ level, respectively. 


\section{Supplementary Files}

This is a list of supplementary files associated with this preprint. Click to download.

- Coverletter.docx 